\title{
Mantle exhumation at magma-poor passive continental margins. Part II: Tectonic and metasomatic evolution of large-displacement detachment faults preserved in a fossil distal margin domain (Saraillé Iherzolites, northwestern Pyrenees, France)
}

\author{
Yves Lagabrielle ${ }^{1, *}$, Riccardo Asti ${ }^{1}$, Serge Fourcade ${ }^{1}$, Benjamin Corre ${ }^{1}$, Pierre Labaume ${ }^{2}$, \\ Jessica Uzel ${ }^{1}$, Camille Clerc ${ }^{3}$, Romain Lafay ${ }^{4}$ and Suzanne Picazo ${ }^{4}$ \\ ${ }^{1}$ Université de Rennes, CNRS, UMR 6118 Géosciences Rennes, Campus de Beaulieu, 35000 Rennes, France \\ 2 Université de Montpellier, CNRS, Géosciences Montpellier, 34095 Montpellier, France \\ 3 LIVE, Université de la Nouvelle-Calédonie, BPR4, 98851 Nouméa Cedex, France \\ ${ }^{4}$ Institute of Earth Sciences, University of Lausanne, Géopolis, 1015 Lausanne, Switzerland
}

Received: 10 January 2019 / Accepted: 3 October 2019

\begin{abstract}
In two companion papers we report the detailed geological and mineralogical study of two emblematic serpentinized ultramafic bodies of the western North Pyrenean Zone (NPZ), the Urdach massif (paper 1) and the Saraillé massif (this paper). The peridotites have been uplifted to lower crustal levels during the Cretaceous rifting period in the future NPZ. They are associated with Mesozoic pre-rift metamorphic sediments and small units of thinned Paleozoic basement that were deformed during the mantle exhumation event. In the Saraillé massif, both the pre-rift cover and the thin Paleozoic crustal lenses are involved in a Pyrenean recumbent fold having the serpentinized peridotites in its core. Based on detailed geological cross-sections microscopic observations and microprobe mineralogical analyses, we describe the lithology of the two major extensional fault zones that accommodated: (i) the progressive uplift of the lherzolites upward the Cretaceous basin axis, (ii) the lateral extraction of the continental crust beneath the rift margins and, (iii) the decoupling of the pre-rift cover along the Upper Triassic (Keuper) evaporites and clays, allowing its gliding and conservation in the basin center. These two fault zones are the (lower) crustmantle detachment and the (upper) cover décollement located respectively at the crust-mantle boundary and at the base to the detached pre-rift cover. The Saraillé peridotites were never exposed to the seafloor of the Cretaceous NPZ basins and always remained under a thin layer of crustal mylonites. Field constraints allow to reconstruct the strain pattern of the mantle rocks in the crust-mantle detachment. A $20-50 \mathrm{~m}$ thick layer of serpentinized lherzolites tectonic lenses separated by anastomosed shear zones is capped by a thin upper damage zone made up of strongly sheared talc-chlorite schists invaded by pyrite crystallization. The cover décollement is a few decameter-thick fault zone resulting from the brecciation of Upper Triassic layers. It underwent strong metasomatic alteration in the greenschist facies, by multi-component fluids leading to the crystallization of quartz, dolomite, talc, $\mathrm{Cr}$-rich chlorite, amphiboles, magnesite and pyrite. These data collectively allow to propose a reconstruction of the architecture and fluid-rock interaction history of the distal domain of the upper Cretaceous northern Iberia margin now inverted in the NPZ.
\end{abstract}

\begin{abstract}
Keywords: North Pyrenean Zone / Saraillé / mantle exhumation / fluid-rock interactions / talc-chlorite schists / greenschist facies / detachment faults / mid-Late Cretaceous

Résumé - Exhumation du manteau au pied des marges passives pauvres en magma. Partie 2: Évolution tectonique et métasomatique des failles de détachement à fort déplacement dans le domaine distal fossile (Iherzolites du Saraillé, Pyrénées NW, France). Dans deux articles compagnons, nous décrivons la géologie et la minéralogie de deux massifs de péridotites serpentinisées représentatifs de la Zone Nord-Pyrénéenne (ZNP) occidentale, le massif d'Urdach (article 1) et le massif du Saraillé (cet article). Les péridotites ont été portées vers des niveaux crustaux supérieurs during l'épisode de rifting
\end{abstract}

*Corresponding author: yves. lagabrielle@univ-rennes1.fr 
pyrénéen crétacé qui a affecté la future ZNP. Elles sont associées à des sédiments métamorphiques pré-rift et à des lambeaux de croûte Paléozoïque déformée durant l'exhumation. Dans le massif du Saraillé, la couverture pré-rift et les minces lentilles de mylonites paléozoïques sont engagées dans un pli couché dont le cœur est formé de péridotites. En s'appuyant sur des descriptions de coupes géologiques, des observations microscopiques et des analyses de minéraux à la microsonde, nous précisons la lithologie de deux failles extensives majeures qui ont permis: (i) la remontée des lherzolites sous l'axe du bassin, (ii) l'extraction latérale de la croûte continentale sous les bordures du rift et (iii), le découplage et le glissement de la couverture pré-rift le long des évaporites et argiles du Keuper. Ces deux zones de faille sont le détachement croûte-manteau et le décollement de couverture situés respectivement à la limite croûte-manteau et à la base de la série pré-rift glissée. Les péridotites du Saraillé n’ont jamais été mises à l'affleurement sur le fond des bassins de la ZNP et sont toujours restées sous une mince couche de mylonites crustales. Les données de terrain permettent de reconstituer l'état de la déformation des lherzolites dans le détachement croûtemanteau. Un niveau de 20 à $50 \mathrm{~m}$ d'épaisseur fait de lentilles tectoniques de serpentinites séparées par des zones de cisaillement anastamosées est surmonté par une zone d'endommagement constituée de talcschistes envahis par de la pyrite. Le décollement de couverture est une zone d'épaisseur pluridécamétrique résultant de la bréchification tectonique du Trias supérieur. Il a subi une forte altération métasomatique par des fluides à composants multiples ayant conduit à la précipitation de quartz, dolomite, talc, chlorite riche en $\mathrm{Cr}$, amphiboles, magnésite et pyrite. Cet ensemble de données sur le massif du Saraillé permet de proposer une reconstitution au Crétacé supérieur de l'histoire des fluides et de l'architecture du domaine distal de la marge Nord Ibérique aujourd'hui inversée dans la ZNP.

Mots clés : Zone Nord Pyrénéenne / Saraillé / exhumation du manteau / interactions fluide-roche / talc-chlorito schistes / faciès schistes verts / faille de détachement / Crétacé moyen-supérieur

\section{Introduction}

Magma-poor hyper-extended rifted margins represent extensional environments with specific thermal, rheological and magmatic conditions. Based on recent geophysical data, the architecture of these structures systematically appears composed of three distinct domains, from continent to ocean: the proximal, necking and distal domains (Peron-Pinvidic and Manatschal, 2009). Crustal stretching is concentrated in the necking domain and exhumation of the subcontinental mantle lithosphere frequently occurs in the distal domain (PeronPinvidic and Osmundsen, 2016). Models explaining the structural evolution of rifted margins generally imply a sequence of distinct fault systems during the three stages of rifting (stretching, thinning and exhumation phases) (e.g. Lavier and Manatschal, 2006; Sutra et al., 2013). Steep faults with up to a few kilometers of vertical displacement accommodate extension in the necking domain and lowerangle faults can accommodate tens of kilometers of horizontal motion in the distal domain. The latter extensional detachment faults control the extreme thinning of the continental crust and, by place, the exhumation of the subcontinental mantle up to the seafloor.

Since current passive margins lie at abyssal depths with difficult access, the finite state of strain and the mechanisms of deformation of the thinned to hyper-thinned continental crust in the necking and distal domains are not directly observed and are most often only suspected. A way to overtake this difficulty is to study inverted necking and distal domains of paleopassive margins preserved as internal units in mountain belts such as the Alps, the Pyrenees, the Zagros and the Caledonides (i.e. Lemoine et al., 1987; Manatschal and Nievergelt, 1997; Manatschal, 2004; Marroni and Pandolfi, 2007; WrobelDaveau et al., 2010; Andersen et al., 2012; Mohn et al., 2012; Chew and Van Staal, 2014; Jakob et al., 2019). These field analogues represent unique geological laboratories that allow direct sampling of the most remote domains of continental passive margins.

The southern European and northern Iberian passive margins collided to form the Pyrenees, but fortunately shortening did not exceed $150 \mathrm{~km}$ (Muñoz, 1992; Roure and Choukroune, 1998; Mouthereau et al., 2014). This was sufficient to allow the distal portions of the magma-poor northern Iberia margin to be uplifted and now exposed all along the northern flank of the belt, in the North Pyrenean Zone (NPZ) (Jammes et al., 2009; Lagabrielle et al., 2010; Masini et al., 2014; Clerc et al., 2016; Corre et al., 2016; Teixell et al., 2016) (Fig. 1). In two companion papers, we describe and discuss the geology of two key-areas of the western NPZ, the Urdach and Saraillé massifs, that preserve remarkable portions of the Iberia margin distal domain (Fig. 2).

The geological frame of this article is the Saraille lherzolite body and associated units which expose remnants of two types of major extensional shear zones responsible for the exhumation of continental units and subcontinental lherzolites beneath a sequence of metamorphic pre-rift sediments (Lagabrielle et al., 2010; Corre et al., 2016). The deepest shear zone separates the ultramafic mantle rocks from strongly thinned Paleozoic continental rocks and is named the crustmantle detachment hereafter (Fig. 3). The shallowest shear zone marks the boundary between mantle or Paleozoic rocks and the base of the detached pre-rift Mesozoic metasedimentary cover: it is named the cover décollement (Fig. 3). Where the hyperthinned crust is completely extracted from beneath the cover décollement, both detachment and décollement faults merge, and the pre-rift sediments lie in tectonic contact on the mantle basement. Our study focuses for the first time on the geometrical characteristics and the internal structure of these fault zones and their mineralogical evolution. We aim defining the state of strain of the crustmantle detachment and cover décollement and we attempt characterizing syn-tectonic fluid-rock interactions along them. 


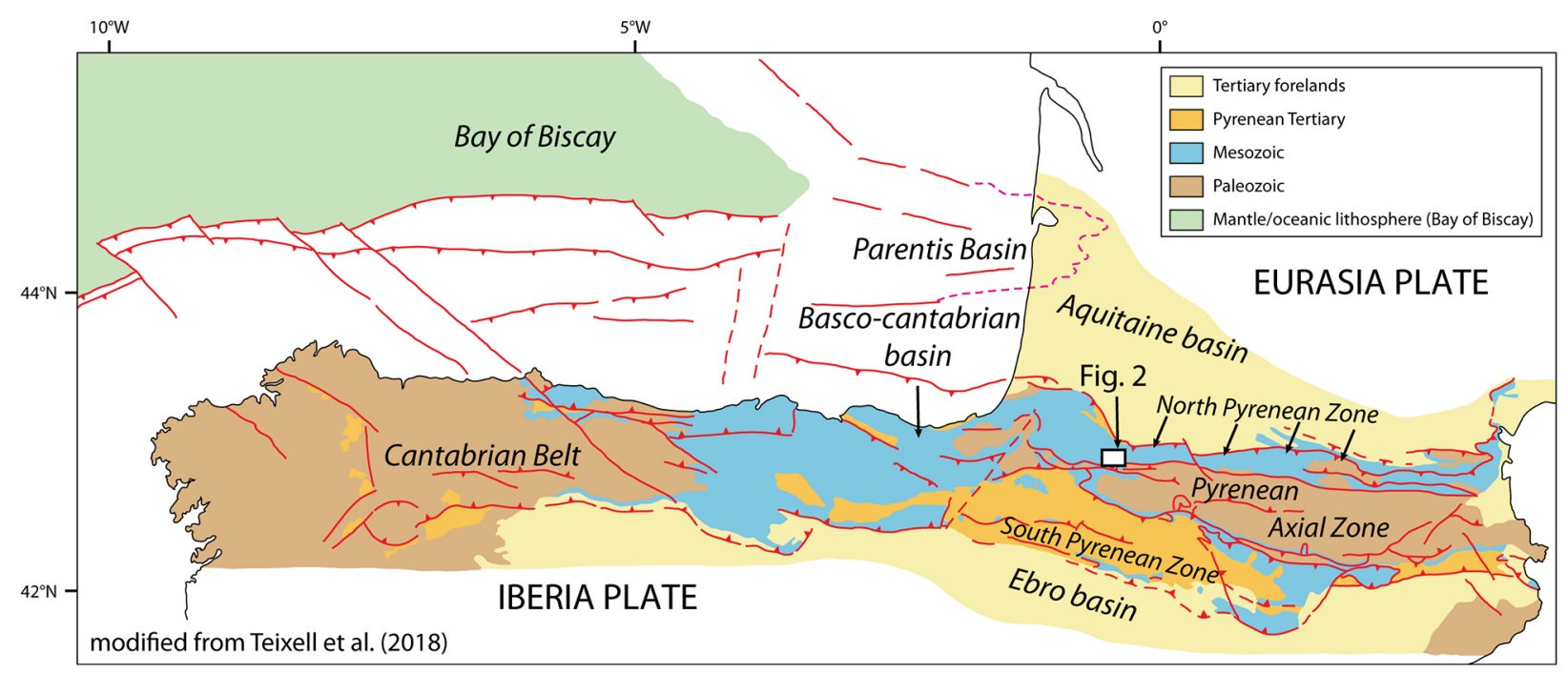

Fig. 1. Simplified structural map of the Pyrenean-Cantabrian belt and location of the study area (after Teixell et al., 2018).

We finally envision the evolution of the entire distal domain during the rifting of the northern Iberia margin, taking into account the geological constraints provided by the Saraillé massif (this study) and the nearby Urdach massif (see companion paper, Lagabrielle et al., 2019).

\section{Geological setting and models of Pyrenean rifting evolution}

\subsection{The Pyrenees and the Iherzolite bodies}

The E-W trending Pyrenean thrust-and-fold belt results from the collision between the margins of the northern Iberia and southern Eurasia plates during the Late CretaceousTertiary (Choukroune and ECORS team, 1989; Roure et al., 1989; Muñoz, 1992; Roure and Choukroune, 1998; Teixell, 1998; Mouthereau et al., 2014; Teixell et al., 2016, 2018). It consists of a core of Paleozoic rocks forming the elevated Axial Zone, bounded to the south by the South Pyrenean Zone (SPZ) mostly formed by detached Mesozoic thrustsheets comprising synorogenic Upper Cretaceous-Tertiary flysch and molasse sediments and to the north by the North Pyrenean Zone (NPZ), a narrow belt of Mesozoic sediments containing remnants of subcontinental mantle rocks (lherzolites) (Monchoux, 1970; Debroas, 1978; Vielzeuf and Kornprobst, 1984; Fabriès et al., 1991, 1998). The NPZ is bounded to the south by the EW-trending North Pyrenean Fault (NPF). Continental rifting in the Pyrenean realm occurred coevaly with oceanic spreading in the Bay of Biscay in relation with the counterclockwise rotation of the Iberia plate during the Cretaceous (Le Pichon et al., 1970; Choukroune and Mattauer, 1978; Olivet, 1996; Sibuet et al., 2004). Rifting leading to crustal separation was accompanied by the ascent of subcontinental lithospheric mantle in the axis of the future NPZ (Vielzeuf and Kornprobst, 1984; Fabriès et al., 1991, 1998; Lagabrielle and Bodinier, 2008; Jammes et al., 2009). Based on their geological setting, the small Pyrenean mantle bodies can be classified within two types (Lagabrielle et al., 2010). In the S-Type (sedimentary type) the lherzolite bodies are included within clastic sedimentary formations.
Emblematic examples are the Lherz body in the Aulus Cretaceous basin and the Bestiac-Prades bodies in the Tarascon basin (Lagabrielle et al., 2016; Saint Blanquat et al., 2016). In the T-type (tectonic type), the lherzolite bodies exhibit tectonic relationships with the surrounding Mesozoic formations of the NPZ. They are most often associated with cataclastic Triassic rocks and with thin tectonic lenses of Paleozoic material.

\subsection{Recent models of Pyrenean rifting evolution}

Exhumation of sub-continental mantle undoubtedly appears as an important mechanism accompanying the processes of extreme thinning of the continental crust during plate separation all along the Pyrenean realm during the midCretaceous transtensional event (Lagabrielle and Bodinier, 2008; Jammes et al., 2009; Lagabrielle et al., 2010; Masini et al., 2014; Tugend et al., 2014; DeFelipe et al., 2017). In addition, correlation between metamorphic and chronological data demonstrates that extensional deformation of the pre-rift Mesozoic sequences and thinning of the continental basement of the NPZ occurred under low pressure and high temperature (LP-HT) metamorphic conditions (Golberg and Leyreloup, 1990; Clerc et al., 2015). On the basis of geological observations, Clerc and Lagabrielle (2014) proposed a mechanism of rifting in the future NPZ involving the lateral extraction of the ductilely thinned and boudinaged Variscan basement under a mobile Mesozoic pre-rift cover decoupled on clays and evaporites of Late Triassic age (Keuper deposits). This finally resulted in the early tectonic juxtaposition of exhumed mantle rocks against the allochthonous pre-rift sediments. In this model, Albian-Cenomanian flysch basins developed progressively above the deforming pre-rift cover during the extension of the future NPZ domain and the HT Mesozoic marbles accommodated the extension at the base of the basin by ductile shear and boudinage. Finally, crustal thinning occurred in a ductile mode leading to a necking domain characterized by single slope conjugate margins (Clerc and Lagabrielle, 2014; Teixell et al., 2016, 2018). This evolution has been reconstructed from different sites along the 


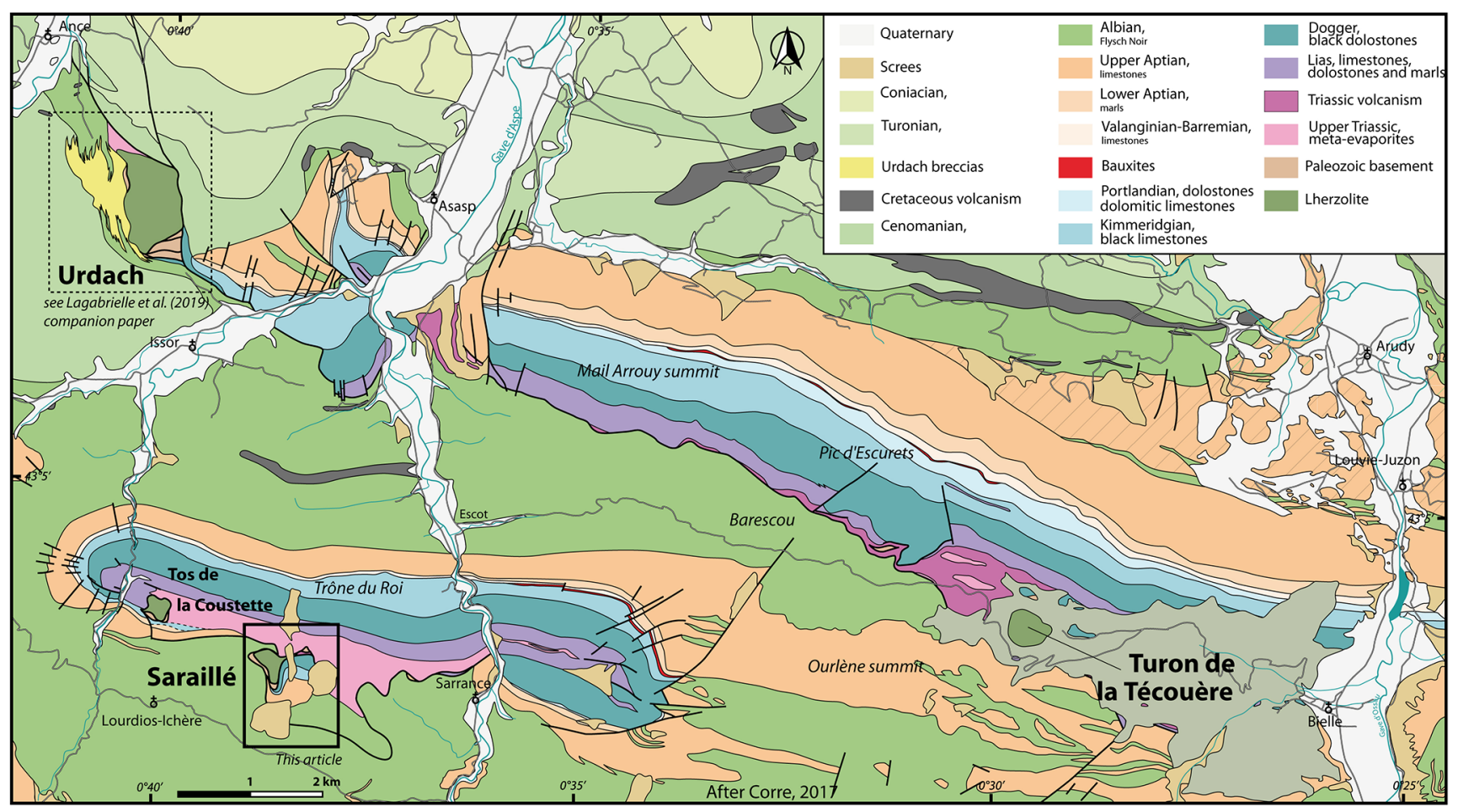

Fig. 2. Geological map of the "Chaînons Béarnais" (Corre, 2017) and location of the Saraillé lherzolite body. See location of the nearby Urdach body studied in the companion paper Lagabrielle et al. (2019).

NPZ, including the Saraillé massif (Corre et al., 2016). This model is consistent with paleomargin architectures lacking extensional allochthons in their distal domain, thus contrasting with former reconstructions from the western NPZ (Mauléon basin: Jammes et al., 2009; Masini et al., 2014).

\subsection{The Chaînons Béarnais and their four mantle bodies (Fig. 2)}

The Chaînons Béarnais range exposes the Mesozoic prerift and synrift sediments of the western NPZ. In its western area, it consists of three E-W trending, parallel fold structures: the Mail Arrouy monocline, and the Sarrance and Layens anticlines, bounded by north- and south-verging, post-Cenomanian thrust faults (Casteras et al., 1970) (Fig. 2). To the west, the structures plunge westward in the Mauléon basin. The stratigraphic sequence of the Chaînons Béarnais consists of basal brecciated metamorphic Upper Triassic sediments (Keuper facies) and ophites, followed by Mesozoic platform carbonates which represent the original cover of the northern Iberian margin (Canérot et al., 1978; Canérot and Delavaux, 1986). This sequence is tectonically disconnected from its former Paleozoic basement known only as very small tectonic slices or breccia fragments. The platform carbonates comprise a succession of Jurassic to upper Aptian metamorphic limestones, dolostones and subordinate marls forming the current main reliefs. Rapid thickness variations of the Mesozoic carbonate layers are attributed to diapiric activity linked to basement faulting starting as early as the Late Jurassic-Early Cretaceous (James and Canérot, 1999). This platform succession terminates with a thick (300-400 m) layer of upper Aptian limestones (Urgonian facies), and is followed by a thick sequence of Albian to Cenomanian flysch deposits preserved within the synclines and marking the main rifting stage ("Flysch Noir and Flysch Gris", Debroas, 1978; Canérot, 2017 and references within). Four main lherzolite bodies reside in the Chaînons Béarnais range: (1) the Saraillé and Tos de la Coustette bodies in the southern flank of the Sarrance anticline; (2) the Urdach body at the western tip of the Mail Arrouy anticline; and (3) the Turon de la Técouère body in the strongly tectonized zone of Benou, along the southern border of the Mail-Arrouy thrust structure (Fig. 2). The Saraillé lherzolites are highly serpentinized and lie in tectonic contact with thin Paleozoic lenses and with ductilely deformed Mesozoic carbonates bearing HT-LP paragenesis (Fortané et al., 1986; Thiébault et al., 1992; Corre et al., 2016). They represent the emblematic example of the T-type lherzolites (Lagabrielle et al., 2010; Corre et al., 2016). The Urdach lherzolites belong to both the T-type and S-type and display a more complex setting involving lenses of Paleozoic rocks and sedimentary crustal-mantle breccias stratigraphically overlying the ultramafic basement. Ultramafic breccias cemented by carbonates (ophicalcites) are observed in the upper part of the Urdach mantle section. Both the ultramaficrich breccias and the ophicalcites formed as the mantle rocks were directly exposed on the floor of the mid-Cretaceous basin (Jammes et al., 2009, Debroas et al., 2010; Lagabrielle et al., 2010; DeFelipe et al., 2017). 


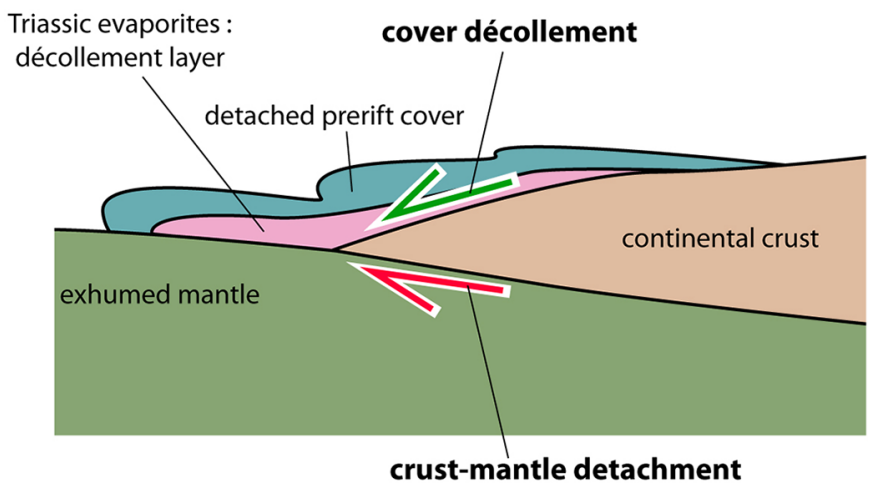

Fig. 3. Cartoon showing the location of the crust-mantle detachment and cover décollement in the distal domain of an idealized passive margin with mantle exhumation and denudation.

\section{Structure of the Saraillé massif: location of the crust-mantle detachments and cover décollements.}

The Saraillé massif (Figs. 4 and 5) exposes a remarkably complete but extremely-thinned lithospheric section including mantle rocks, continental crustal rocks and their Mesozoic sedimentary cover. These various rocks are relatively well exposed along the north-east side of the massif, from an elevation of $960 \mathrm{~m}$ up to the Saraillé summit at $1240 \mathrm{~m}$, thus offering a $280 \mathrm{~m}$ thick section. The Saraillé peridotites are composed of up to $100 \%$ serpentinized lherzolites and minor centimeter-thick veins of pyroxenites, mostly websterite (CPX+OPX) (Gaudichet, 1974) that result of refertilization processes of probable Permian age (Le Roux et al., 2007). The structure of the Saraillé massif corresponds to a south-verging recumbent fold which overthrusts the southern flank of the Sarrance anticline (Corre et al., 2016) (Figs. 4 and 5). The fold involves a layer of strongly thinned Mesozoic pre-rift carbonates wrapping an elongated core of Paleozoic basement rocks. This core is $500 \mathrm{~m}$ long and $100 \mathrm{~m}$ thick and consists of an assemblage of thin elongated lenses of sheared Paleozoic crustal rocks (e.g. sample BCOR15, Fig. 6A) welded to the serpentinized lherzolites. The mantle rocks are separated from the crustal lenses by the crust-mantle detachment including intensively sheared serpentinzed, talc-rich ultramafic rocks (e. g. sample BCOR19, Fig. 6B). The crustal lenses are exposed in the hinge and in the reverse flank of the recumbent fold. They are dominated by quartz-rich and chlorite- or mica-rich mylonites (e.g. sample SAR13, Fig. 6C) and less deformed granitoids crossed by undeformed to slightly sheared thin albitite veinlets (Asti et al., in prep.). The mylonitic foliation of the crustal lenses parallels the contact with the peridotites as already emphasized by Corre et al. (2016). Some samples display a post-mylonite tectonic brecciation (Fig. 6A), thus recording the ductile/brittle transition as often described along major detachment faults (i.e., Reynolds and Lister, 1987).

The cover décollement of the Saraillé massif runs at the base of the detached Mesozoic cover. It corresponds to tectonically dismembered Upper Triassic metasediments and meta-ophites associated with large volumes of metasomatic rocks. The overlying Jurassic metasediments comprise ductilely deformed dolomitic marbles, up to $100 \mathrm{~m}$ thick. The Neocomian sequence corresponds to an alternation of decimetric beds of pure marbles and dolomitic or phyllite-rich marbles. It has been ductilely thinned during the Albian extension, but earlier thickness reduction may have occurred during the Late Jurassic due to an erosional phase and diapiric activity that affected the entire region (Canérot and Delavaux, 1986). Dolomitization decreases toward the top of the sequence (Corre et al., 2018). The Upper Aptian Urgonian facies platform carbonates form the top and the southern flank of the Saraillé massif (Fig. 4). The Albian "flysch noir" is largely exposed on the southern flank of the mountain. It consists of an alternation of metamorphic black marls, siltites and limestones. The Jurassic to Albian metasediments are intensively recrystallized and cross-cut by numerous carbonate veins that record circulation of brines expelled from the Keuper clays and evaporites during the extensional Cretaceous event (Salardon et al., 2017; Corre et al., 2018).

The Saraillé carbonates are dissected by at least three schistosities. In the entire Mesozoic sequence a S1 foliation parallels the stratigraphic bedding (S0) and is marked by the alignment of sheared calcite crystals and by the flattening of macrofossils, microfossils and biogenic clasts, perpendicular to the S0 plane. At the thin-section scale, the most deformed sample display multiple shear bands and a mylonitic fabric characterized by dynamic recrystallization of calcite (sample SAR5 Fig. 6D). Numerous calcite veins are boudinaged, indicating extension in the S0/S1 plane. These observations collectively confirm the early tectonic flattening of the sedimentary pile that occurred partly during the AlbianCenomanian extensional phase (Corre et al., 2016). Similar observations are reported from numerous places along the NPZ (Vauchez et al., 2013; Clerc et al., 2016; Ducoux et al., in press). The S2 schistosity planes are subhorizontal and parallel the axial plane of the recumbent fold. They generally cross-cut the S0/S1 foliation at low angle. There are no age constraints concerning the development of the Saraillé recumbent fold and its related subhorizontal S2 schistosity. Both may have formed immediately after the main extensional event that led to $\mathrm{S} 0 / \mathrm{S} 1$ formation, during either the rifting period or in the early stages of the compressional evolution. The S3 schistosity planes are steeply dipping and trend roughly E-W. They developed in response to the Pyrenean compression that led to the current structure of the Sarrance anticline.

The geological environment of the T-type Saraillé lherzolites is devoid of sedimentary breccias reworking ultramafic material. Instead, the peridotites are only separated by early tectonic contacts with the pre-rift cover (Canérot and Delavaux, 1986; Lagabrielle et al., 2010). By contrast to the Urdach lherzolites, the Saraillé lherzolites were not directly exposed to the seafloor of the Albian basins and remained below a blanket of hyper-thinned Variscan basement units and pre-rift meta-sediments during the mid-Cretaceous extensional event (Lagabrielle et al., 2010).

\section{Anatomy of the crust-mantle detachment and cover décollement in the Saraillé massif. Microstructures and mineralogy}

In the following subsections, we first propose a description of the studied outcrops. The petrographic and mineralogical 


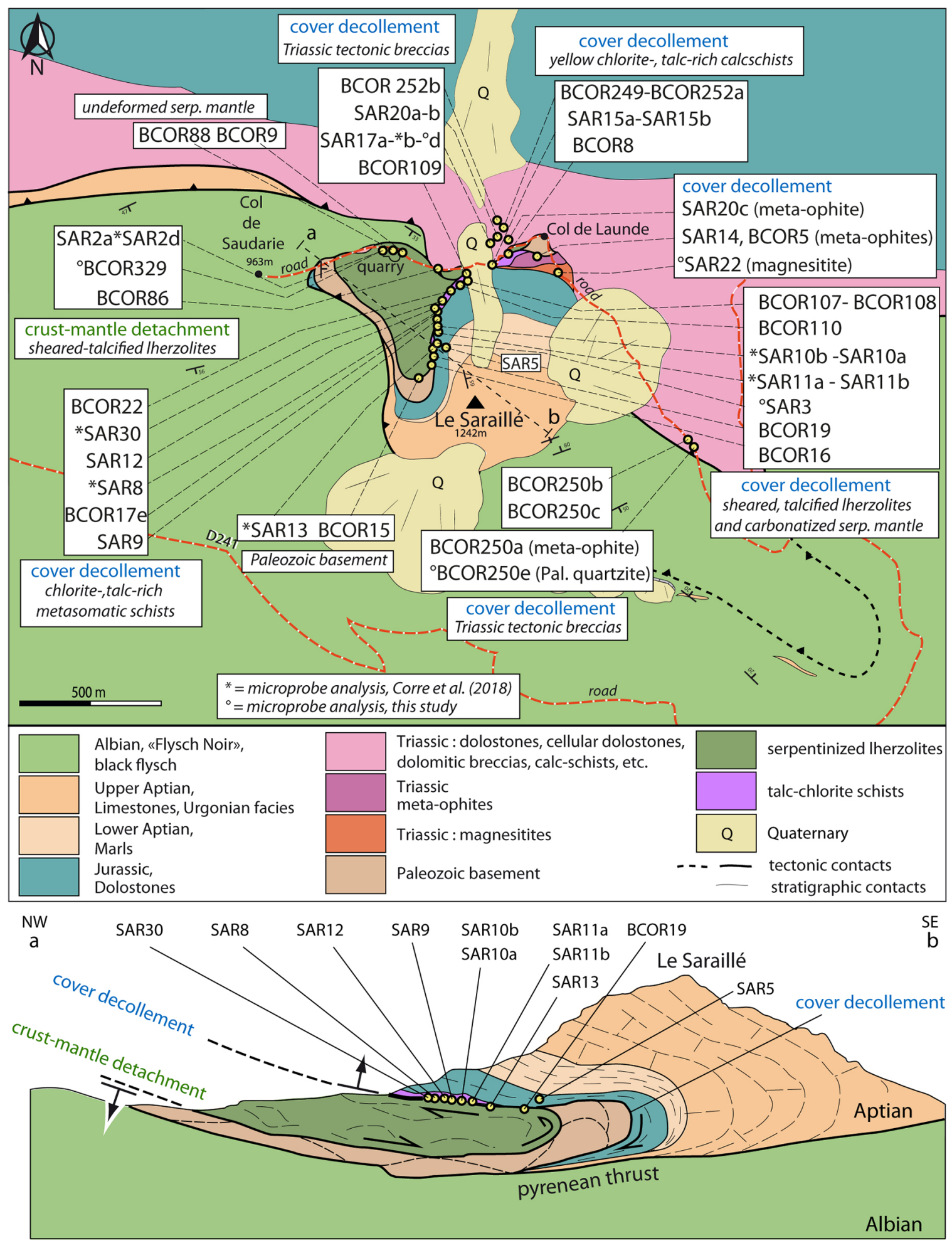

Fig. 4. Detailed geological map of the Saraillé massif (modified from Corre, 2017) and corresponding geological cross-section a-b. Location of all studied samples. 

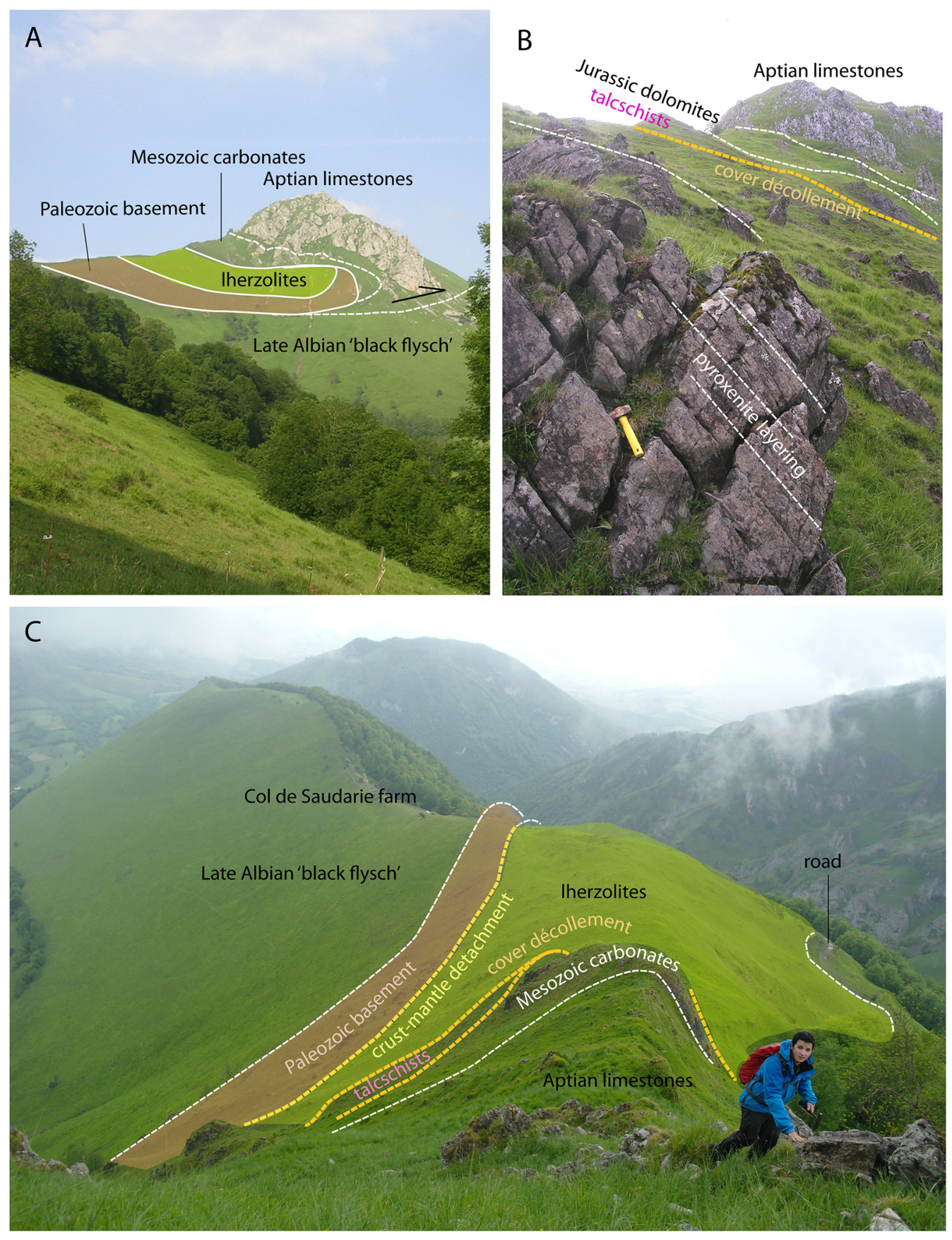

Fig. 5. Photographic plate showing some important panoramas of the Saraille massif. A. General view looking to the east from the bottom of the valley, near Lourdios. B. View from the base of the Saraillé summit looking toward the east. The closest outcrops are mantle lherzolites showing undeformed pristine layering. In the background, the cover décollement corresponds to the talcschists level. C. View toward the west from the base of the Saraillé summit.

descriptions of samples cited in this field data section are presented in the Supplementary Material section. Location of the studied samples is reported on the geological map of Figure 4.

\subsection{The Saraillé crust-mantle detachment and the uppermost mantle}

\subsubsection{Field data}

The Saraillé crust-mantle detachment corresponds to the limit between the ultramafic rocks and the Paleozoic lenses (see cross-section in Fig. 4). On the northern side of the lherzolite body, it lies in a reverse position and undulates almost horizontally parallel to a forest road joining Col de Launde to Col de Saudarie. Here, most of the exposed lherzolites are not deformed (samples BCOR9 and BCOR88) and the pyroxenite layering is almost parallel to the road (see stereonets in Corre et al., 2016). The crust-mantle detachment is exposed only in two places, where it is crossed by the road, on the eastern and western sides of the mantle body (samples BCOR86, BCOR329, SAR2). A quarry located along the road 

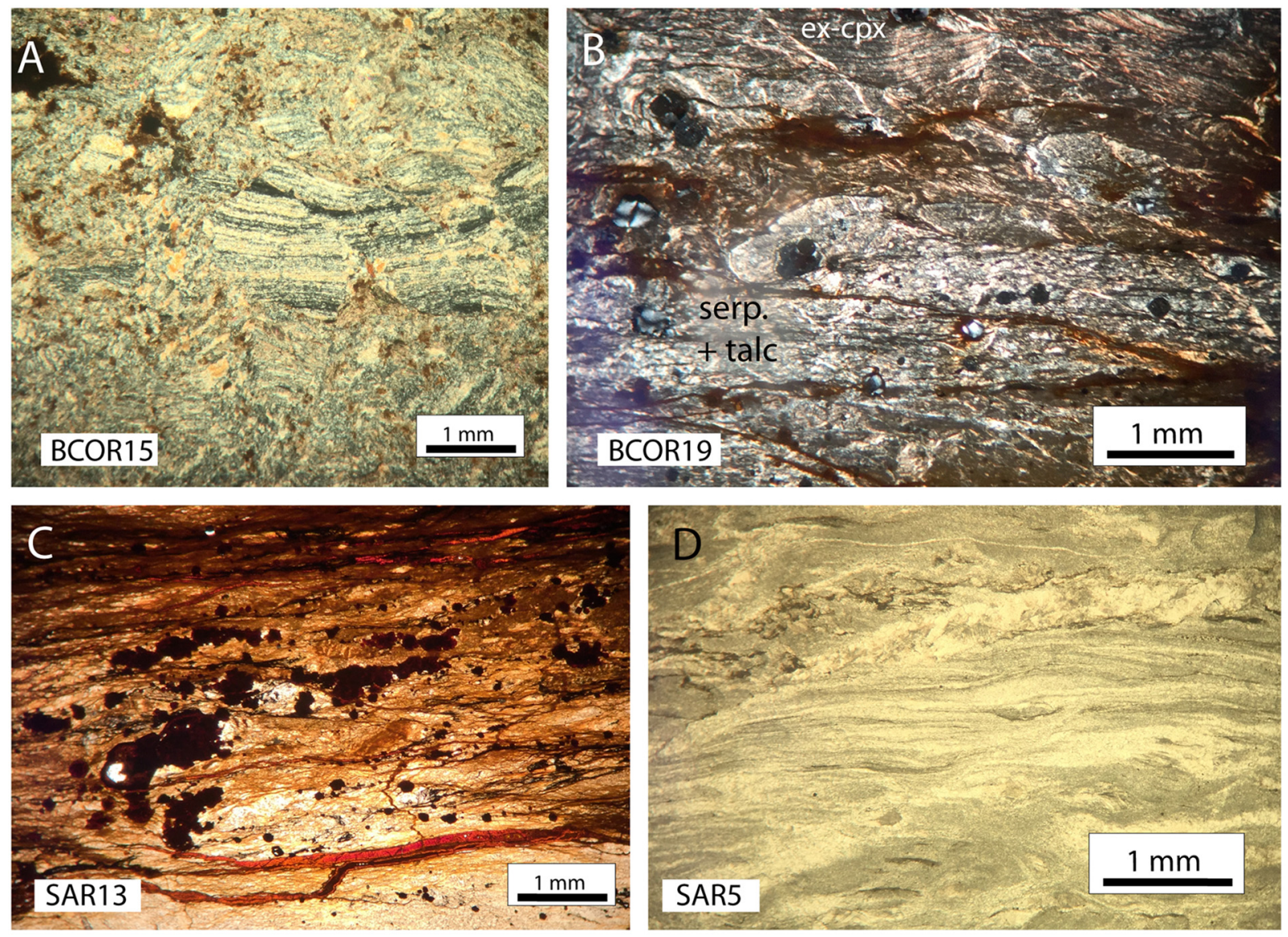

Fig. 6. Microphotographs showing some emblematic tectonic fabric in formations involved in the processes of mantle exhumation. A. Tectonic breccia after a mylonitic gneiss in the Variscan units. This sample recorded the ductile/brittle transition (BCOR15). B. Microfolds and shear bands in a talcified mantle rocks of the damage zone (crust-mantle detachment) (BCOR19). C. Shear fabric in a chloritized Paleozoic tectonic lens along the crust-mantle detachment (SAR13). D. Ductile deformation in a Mesozoic marble from the pre-rift cover (SAR5).

(Figs. 4 and 7A), close to Col de Saudarie, allows observations in the peridotite $10-50 \mathrm{~m}$ away from the crust-mantle detachment. Here, the serpentinized lherzolites are cross-cut by a network of anastomozing shear zones delineating a series of symmetrical tectonic lenses, roughly $1-3 \mathrm{~m}$ thick and a few meters long (Lagabrielle et al., 2010 and Fig. 7A). The long axes of the lenses are roughly parallel between them and dip to the south-west. The core of the lenses is not affected by internal shearing (sample BCOR9 and Fig. 7B) but is cut by a network of tight N-S trending vertical fractures. Slickensides and striae are systematically observed on the low angle serpentine fault surfaces bounding the lenses. Along the best exposed planes, they define a E-W trending lineation. An additional network of discrete subvertical fault surfaces cut the lenses in the E-W trending direction. These surfaces bear light green serpentinous surfaces with a rough slickenside lineation dipping westward by $45^{\circ}$ (see Fig. 7 for more details). The symmetrical geometry of the tectonic lenses suggests a coaxial deformation regime and an overall flattening of the mantle body (Figs. 7C and 7D). Frequent fibrous serpentine minerals that develop on the fault surfaces indicate syn-tectonic serpentinization. Rare carbonate veinlets are the witness of a limited carbonation. To sum up, a 20-50 m thick deformed layer of anastomozing shear bands cutting through the serpentinized lherzolites and displaying evidence of syn-tectonic serpentinization is identified here. This layer is named the lenticular layer in the following.

On the east side of the quarry, we observe a few metersthick damage zone which structurally overlies the lenticular layer (Figs. 8A and 8C). It consists of an assemblage of centimeter-sized symmetrical lenses of a soft, phyllite-rich, sheared material, separated by a network of anastomozing conjugate shear zones associated with cataclastic layers (samples SAR2a and SAR2d; Fig. 8A). The lenses are aligned along a well-marked foliation gently dipping to the west (N0W10, N120SW20, N155W26). The uppermost shear bands display a dark-green to light-green colour whilst basal shear bands display alternating orange, light-yellow, and white colors (Fig. 8C). Both include lens-shaped clasts of less deformed material. The upper green layers derive directly from intense tectonic shearing of the serpentinized lherzolites. The basal yellow and white layers display typical aspects of chloritized and talcified ultramafic rocks. Some grey horizons at the base of the outcrops apparently derive from intensively crushed Paleozoic rocks. Kinematics criteria often indicate opposite displacements along both sides of the tectonic lenses. 


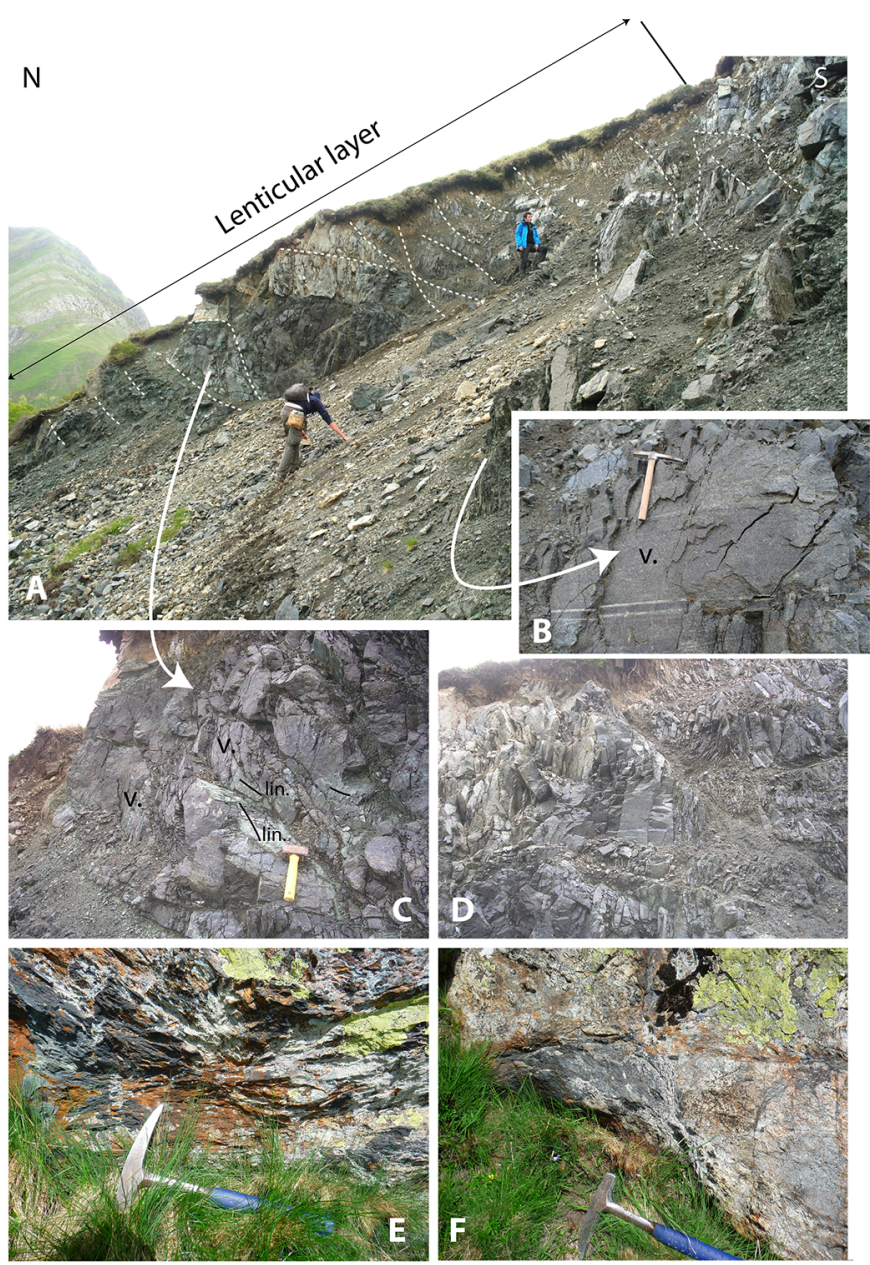

Fig. 7. The lenticular layer in the Saraillé crust-mantle detachment. A. General view of the Col de Saudarie quarry showing the phacoidal fabric with decameter-sized tectonic lenses. B. Detailed view of the core of a fully serpentinized mantle lens showing undeformed pyroxenite layering. C. Detailed view of a tectonic lens (phacoid) exposed along the eastern edge of the quarry. Some serpentine fibers define a local lineation (lin.) on the shallow dipping surface of the phacoid. Lineation can be observed locally on subvertical planes (v.) cross-cutting the phacoids. D. Detailed view of a series of tectonic lenses cross-cut by tight $\mathrm{N}-\mathrm{S}$ trending fractures. Note that some fractures are deformed and show curvatures in relation with late gliding along the shallow dipping surface of the phacoids. Gliding may relate here to slope unstability. E and F. Detailed view of the phacoidal fabric in the lenticular layer on the Saraillé western flank.

Therefore, no homogeneous sense of shear can be deduced at the scale of the outcrop. Here also, a deformation regime by a combination of layer-parallel shearing and layer perpendicular shortening is observed. A core of $20 \mathrm{~cm}$ diameter of these soft fault rocks was obtained and prepared for thin section (sample BCOR329c, Figs. 8B and 8C).

The upper limit of the damage zone corresponds to the boundary with the Variscan material. This limit is observed in one place only, west of the serpentine quarry, close to Col de Saudarie (Figs. 8D1 and 8D2). Here, the contact with the underlying crustal gneisses is very sharp and dips to the east at moderate angle (N10E35). The gneisses display a mylonitic
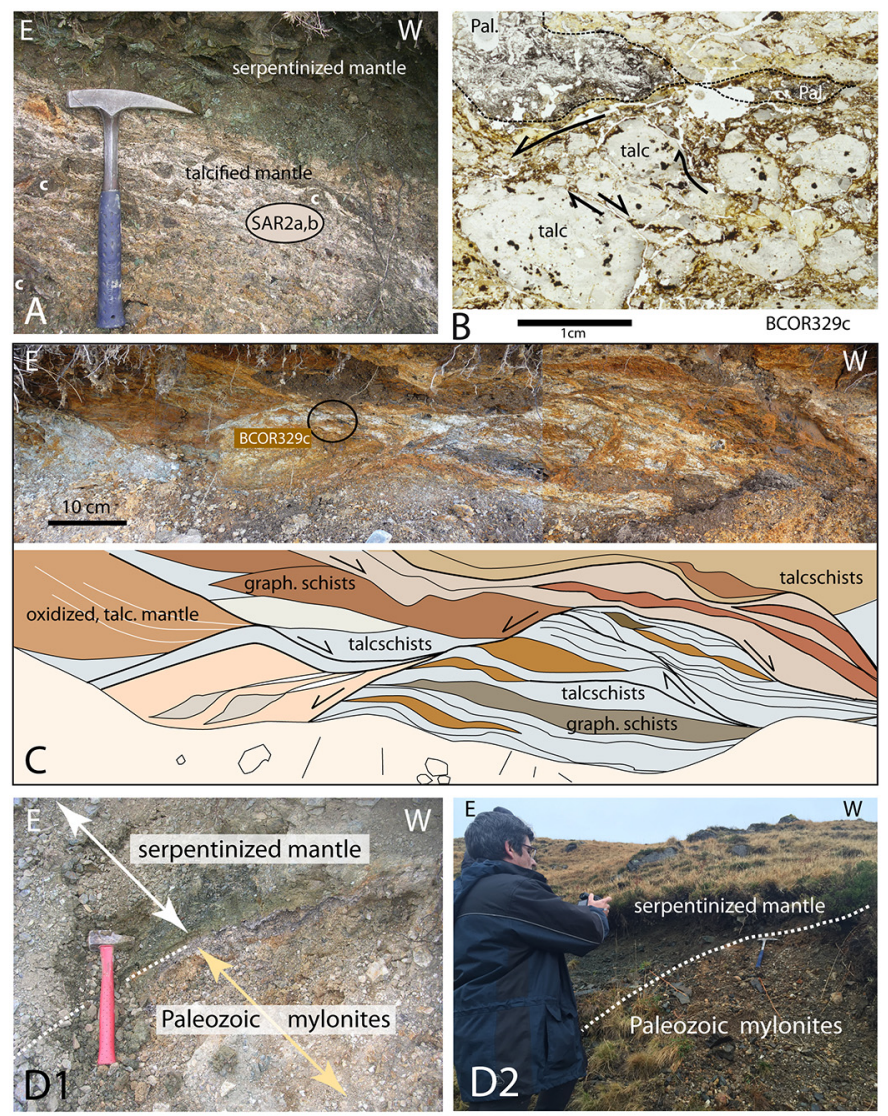

Fig. 8. Fabric and microfabric of the Saraillé crust-mantle detachment: the damage zone at sites of samples SAR2a, SAR2b and BCOR329 (road to Col de Saudarie, see Fig. 4 for localization). A. Serpentinized and talcified sheared mantle (samples SAR2a, SAR2b). B. Thin section of sample BCOR329c. Note the clasts of Paleozoic material (pal.) mixed with talcschist fragments in a talc-rich gouge. $C$. Tectonic lenses at site of sample BCOR329c. D1 and D2. The upper limit of the damage zone corresponds to the boundary with the Variscan material. It is observed west of the serpentine quarry, close to Col de Saudarie. Note the sharp contact with the underlying crustal gneisses (dip of contact: N10E35).

fabric paralleling the crust-mantle contact and the lenticular fabric of the damage zone in the lherzolites. This important geometrical characteristic is discussed in Asti et al. (2019). It strongly suggests that a parallel foliation developed in both the mantle and crustal material during displacement along the crust-mantle detachment. Complementary description of the continental material sampled all along the Saraillé crustmantle detachment is provided by Asti et al. (2019).

A contact zone between mantle and crustal rocks supposedly exists at the northeastern corner of the Saraillé lherzolites, where the road crosses the southern boundary of the Triassic core of the Sarrance anticline (Fig. 4). Here, a meter-wide fault zone exposing a consolidated cataclastic ultramafic breccia represents the uppermost mantle (sample BCOR86). Loose blocks at the foot of the exposure are composed of cellular dolostones and felsic mylonites cross-cut by veins filled with geodic albitites that derive from the continental basement and the pre-rift cover. 
Unfortunately, the detailed relationships between these lithologies cannot be reconstructed.

The crust-mantle detachment can be followed from south to north along the hinge and upper limb of the Saraillé recumbent fold, in a normal position. At the northern tip of the Variscan basement lenses, it merges with the cover décollement. From this place towards the north, the merged fault zones run at the base of the scarps of the Saraille summit and separate the lherzolites from the attenuated and ductilely deformed pre-rift sedimentary sequence (Corre et al., 2016, 2018). Along this contact, we identified a $500 \mathrm{~m}$-long succession of tectonic lenses, a few meters thick and tens of meters-long each, displaying various compositions. The lenses consist either of strongly metasomatized protoliths or of newly formed metasomatic lithologies. Among the first type, both metasedimentary and ultramafic protoliths can be recognized. The lenses composed of metasomatized ultramafic rocks belong to the uppermost mantle and represent the damage zone of the crust-mantle detachment: samples SAR3, SAR10a-b, SAR11a-b, BCOR16, BCOR19, BCOR107, BCOR108, BCOR110 (Fig. 4). The microstructure and mineralogy of these samples are described in the section A1 Supplementary Material. The lenses deriving from metasedimentary protoliths are composed of talc- and chlorite-rich schists containing dolomitic aggregates, devoid of any mantle derivation (samples SAR8, SAR9, SAR12, SAR30, BCOR17e). These metasomatic schists strongly reacted with Triassic-derived fluids during the Albian-Cenomanian extensional event (Corre et al., 2018) and we may consider that they first evolved in the cover décollement before they came into contact with the mantle rocks. They are considered as part of the cover décollement and are described below in subsection B1.

\subsubsection{Microscopic study and mineralogy}

This section appears in section A1 of Supplementary Material at the end of the manuscript.

\subsection{The Saraillé cover décollement}

\subsubsection{Field data}

The cover décollement of the Saraillé massif corresponds to the base of the detached Mesozoic cover. It can be studied in the northwestern half of the Saraille area. Where the Triassic beds are missing, such as on the top of the slopes east of Col de Saudarie, the cover décollement is represented by metasomatic schists deriving from fluid interactions with Mesozoic sedimentary material. These schists have been sampled in distinct exposures along a distance of $800 \mathrm{~m}$, beneath a continuous layer of cataclastic Jurassic dolostones that formed during displacement along the cover décollement (samples SAR8, SAR9, SAR12, SAR30, BCOR17e) (Fig. 4). These yellowish to pink talc-chlorite schists are composed of anastomosed decimetric to centimetric tectonic lenses, generally of symmetrical shape, locally cross-cut by a network of carbonate veins (e.g. site of sample SAR30, Fig. 9A). They often include lenses of brownish carbonate clastic material and strings of brown dolomitic grains. By place, pyrite grains aligned in the foliation planes are numerous and are locally transformed into hematitic material (e.g. SAR30, Figs. 1SJ and 1SK). Dissolution of the iron oxides and precipitation of
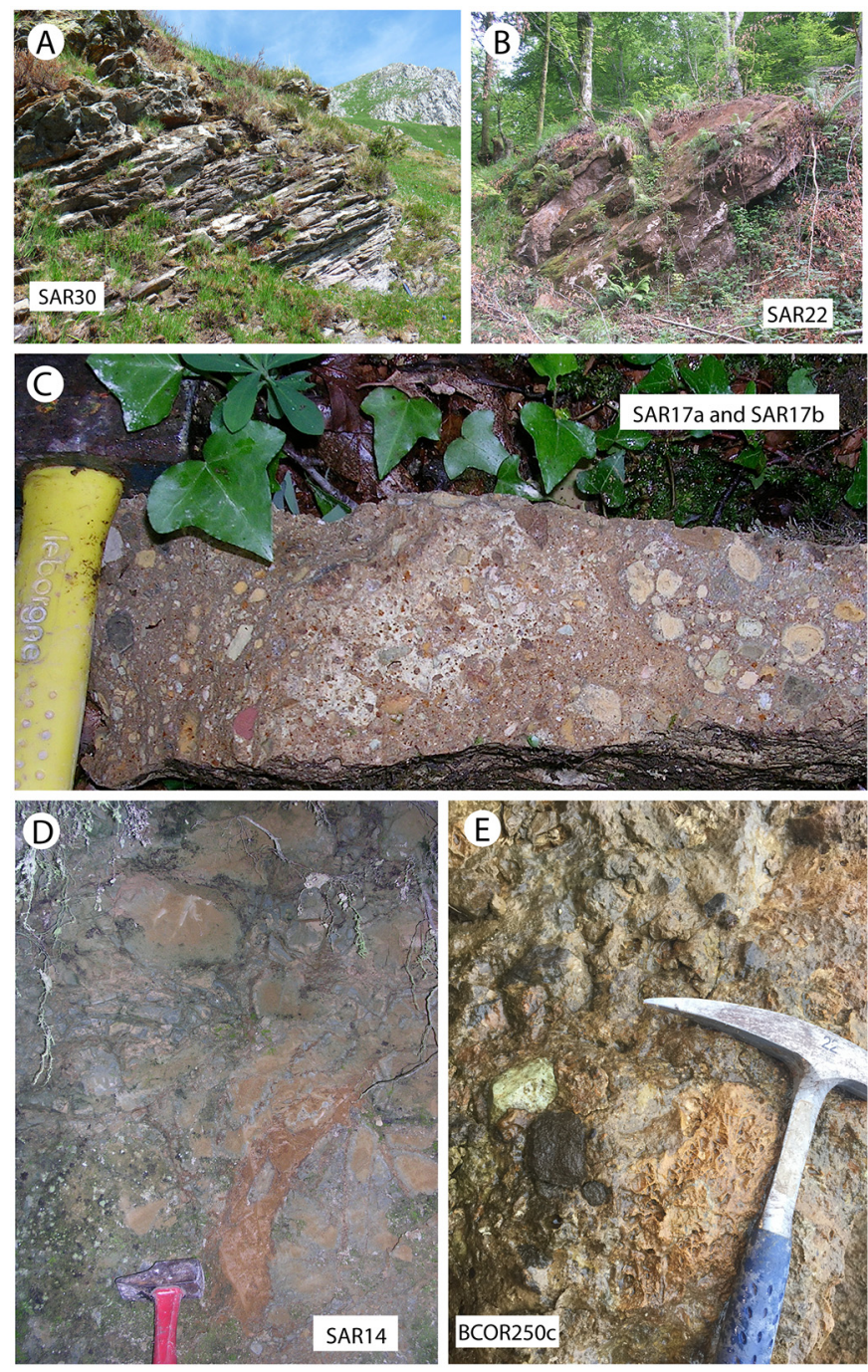

Fig. 9. The cover décollement and the cataclastic Triassic breccias in the Saraillé area: some field aspects. A. 20-30 m thick strongly sheared pink chlorite-talcschists at site of sample SAR30. B. Wellbedded Upper Triassic carbonates entirely changed into a 3-5 m thick magnesitite level (site of sample SAR22). C. Polymictic Triassic tectonic breccias (site of samples SAR17a and SAR17b). D. Brecciated meta-ophite (site of sample SAR14). E. Polymictic Triassic tectonic breccia including clasts of meta-ophite (green), Paleozoic schist (black) and cellular dolostone ("cargneules") (site of sample BCOR250c).

hydroxides locally led to a cellular texture and the development of bright orange-yellow colors (e.g. BCOR17e, Fig. 1SI and SAR12, Fig. 3SA). Quartz veining is present locally in the talc-chlorite schists and enabled study of fluid inclusions (Corre et al., 2018). To the north-east of the study area, the talcchlorite schists pass to outcrops of well-bedded brown Triassic metasomatic carbonates that can be observed along the road to Col de Launde (site of sample SAR22, Fig. 9B). The millimetric neoblasts of sample SAR22 are remarkably homogeneous in size and give to this very hard rock an equigranular aspect (Fig. 5SF). 
In the region north and east of the Saraille summit, the Triassic beds are systematically dismembered and the original stratigraphical succession is never preserved. The cover décollement corresponds to discontinuous exposures of disrupted material with dominating brown to yellow-orange colors. Two main types ( $\mathrm{a}$ and $\mathrm{b}$ ) can be distinguished. (a) Yellow talc-rich calcschists with granular aggregates of brown dolomite and oxidized pyrite grains (samples BCOR8, SAR15a, SAR15b, BCOR249 and BCOR252a, Fig. 4); (b) Cataclastic breccias composed of angular clasts made of brown dolomite, various proportions of light-green altered metaophites and grey felsic rocks deriving from a Variscan basement in a matrix of thinly recrystallized carbonates (samples SAR17a-b, SAR20a-b and BCOR109, Fig. 9C). The largest carbonate clasts most often correspond to brecciated brown dolostones cross-cut by numerous calcite veins (hydrofractured breccia, sample BCOR252b, Fig. 4SH). Recent rock-slide on the west side of the main road, about one $\mathrm{km}$ south of $\mathrm{Col}$ de Launde, allowed significant sampling of the cover décollement. Here, the Triassic cataclasites are dominated by hydrofractured brown dolomites (sample BCOR250b, Fig. 6SD) cemented by a thin-grained polymictic breccia including centimetric angular fragments of dark-brown and orange dolomites and rare light green meta-ophite (sample BCOR250c) (Fig. 9E and Figs. 4SE and 4SF). Between the largest dolomitic clasts, the breccia cement is coarser and includes centimetric fragments of various origins. One of these fragments is a chloritized meta-ophite (BCOR250a, Fig. 5SE). We collected additional thinly crystallized meta-ophites (samples SAR14, Fig. 9D, SAR20c and BCOR5).

\subsubsection{Microscopic study and mineralogy}

This section appears in section A2 of Supplementary Material at the end of the manuscript.

\section{Discussion}

In the following sections, we first propose a synthesis of the crust-mantle detachment and cover décollement internal structure based on the geological observations listed above. We then discuss the significance of the pervasive serpentinization of the Saraillé body, attempting to integrate this metasomatic hydration at the scale of the entire passive margin. We finally discuss the fluid/rock interactions that led to the synkinematic metasomatic transformations along the crustmantle detachment and cover décollement.

\subsection{Structure of the Saraillé crust-mantle detachment and cover décollement: geodynamical implication for rifting processes}

\subsubsection{Crust-mantle detachment}

In the Saraille recumbent fold, the reconstructed crustmantle detachment appears composed of two layers from base to top: a 20-50 m thick deformed layer of anastomosed shear bands defining a lenticular fabric in the serpentinized lherzolites, followed by a few meter thick damage zone consisting of centimeter-sized symmetrical tectonic lenses where the serpentinized mantle rocks are intensively sheared and talcified. Both layers show a deformation regime by a combination of layer-parallel shearing and layer perpendicular shortening. In one place along the damage zone, we found microscopic Paleozoic and Triassic clasts that were incorporated during high-distance displacement along this exhumation contact (samples BCOR329c and BCOR86, Fig. 8 and Fig. 1S).

The synthetic map and cartoons in Figure 10 provide interpretations of the crust-mantle detachment structure. Field observations along sections 1, 2 and 3 (Fig. 10) allow us to constrain the main characteristics of the lenticular layer and damage zone, and help designing the simplified sketches of Figures $10 \mathrm{~B}$ and 10C. Cartoon in B shows the tectonic lenses of the lenticular layer affected by vertical fracturing, and the transition toward the damage zone characterized by talc breccia (gouges), beneath the felsic mylonitic crust. Metasomatic processes including mainly talcification and carbonation of the serpentinized mantle are shown. Local development of talc-chlorite paragenesis is indicated. The numerous serpentine slickensides and fibers observed on the fault surfaces bounding the tectonic lenses of the lenticular layer confirm that serpentinization has been active during displacement along this fault zone (Fig. 10).

Direct constraints for the thermal conditions of deformation in the distal margin domain are provided by the fabric of the Paleozoic basement rocks. Based on quartz microfabric, temperature conditions of $300-450{ }^{\circ} \mathrm{C}$ are obtained for the deformation of the Saraillé and Urdach Paleozoic mylonites by Asti et al. (2019). As argued by these authors, the parallel attitude of the foliation in the Saraille Paleozoic mylonites and in the crust-mantle detachment strongly suggests a mechanical coupling between the mantle lenticular layer and the crustal mylonites during the extension. In addition, dating of the mylonitic event in a crustal lens of the Urdach massif (sample URD24a, Ar/Ar on single muscovite) confirms that the crustmantle detachment was active at $+/-105 \mathrm{Ma}$, that is during the NPZ Albian extensional event (Asti et al., 2019). These data collectively indicate that the mantle lenticular layer started deforming at maximum temperatures of $450{ }^{\circ} \mathrm{C}$, synchronously with the pervasive deformation of the crust. We note that these conditions are compatible with active serpentinization, as discussed in the following section. Temperatures deduced here are slightly higher than those obtained for the rifting of the West-Iberia margin. Indeed, based on oxygen stable isotopes, Skelton and Valley (2000) have shown that the onset of serpentinization of the Iberia mantle during the Aptian rifting, in relation with the southern North Atlantic Ocean opening, was associated with gouge formation and occurred at temperatures below $300^{\circ} \mathrm{C}$. It was followed by secondary fluid infiltration of cooler seawater (below $100^{\circ} \mathrm{C}$ ) along normal fault scarps which occurred during seafloor exhumation of the serpentinized mantle.

The transition from the lenticular layer to the damage zone represents a significant change in the strain regime along the crust-mantle detachment, passing from a $20-50 \mathrm{~m}$ thick deforming zone to a thin localized fault zone. In the Saraillé damage zone, microstructures and mineralogy indicate successive deformation mode: (i) gliding along anastomosed talc-rich surfaces in greenschist facies conditions and, (ii) brittle behaviour of the talcified fault rocks with rotation of rigid micro-blocks that indicates deformation in colder 

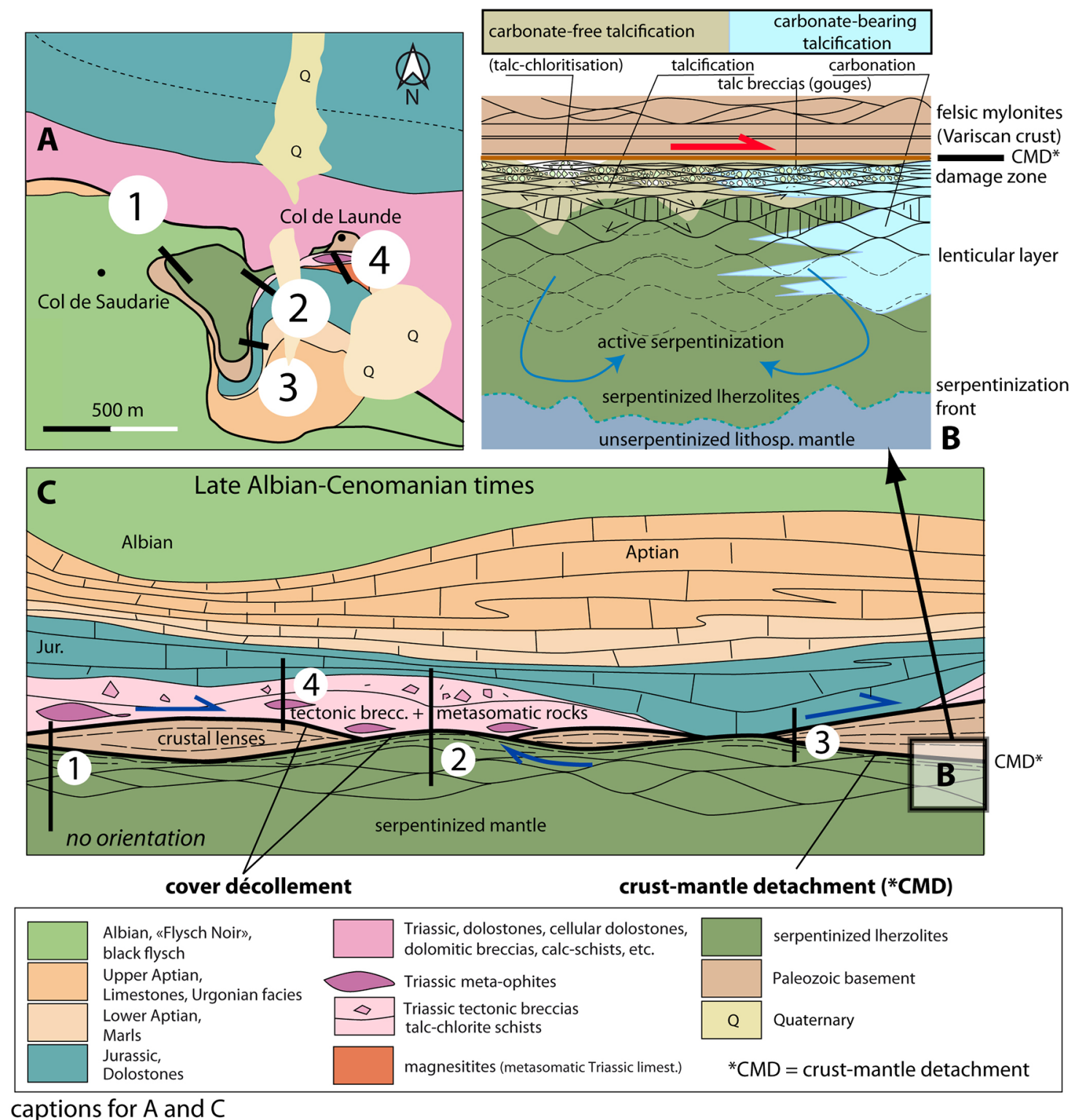

captions for $\mathrm{A}$ and $\mathrm{C}$

Fig. 10. The Saraillé crust-mantle detachment and cover décollement: a tentative of representation of field relationships and conceptual reconstructions. Map in A shows the location of logs used in $\mathrm{C}$ to propose the 2D reconstruction of the various terrannes involved in the mantle exhumation process. Cartoon in B (see location in C) is a detail of the crust-mantle detachment. Refer to detailed explanations in text.

conditions (talc gouges). A similar two-fold deformation mechanism is described along shallow detachment surfaces of oceanic core complexes (OCC) of the Mid-Atlantic ridge and in ophiolitic massifs, with late cold gouges superimposed to greenschist facies soft fault-rock assemblages (e.g. Boschi et al., 2006; Picazo et al., 2012). Strain localization in greenschist facies conditions is driven by a significant fluid input allowing long-lived gliding and the correlated growth of weakening hydrous minerals (chlorite and talc), as exemplified along the San Andreas fault (Moore and Lockner, 2008). Based on these references, we may infer that the initiation of the Saraillé damage zone started in very shallow conditions, when the thickness of the hyper-thinned crustal units decreased to their current values, that is $100-50 \mathrm{~m}$ maximum, as constrained by field data. Therefore, fluid circulations at the top of the lenticular layer followed by embrittlement in shallow and cold conditions allowed an efficient weakening at the crust-mantle boundary that probably accelerated the final stages of the margin evolution.

We compiled field views of lenticular layer from three mantle bodies from the NPZ: Bestiac (east-central Pyrenees: de Saint Blanquat et al., 2016), Moncaup (central Pyrenees: Lagabrielle et al., 2010) and Moncaut (eastern Chaînons Béarnais) (Fig. 11). Comparison with photographs in Figure 7 shows that the lenticular fabric of the Saraillé crust-mantledetachment is very similar to fabrics observed in these massifs. A similar conclusion arises from the study of the Urdach body (see companion paper Lagabrielle et al., 2019). As a consequence, further studies would check that the development of a 20-50 m thick shear zone in the serpentinized mantle 

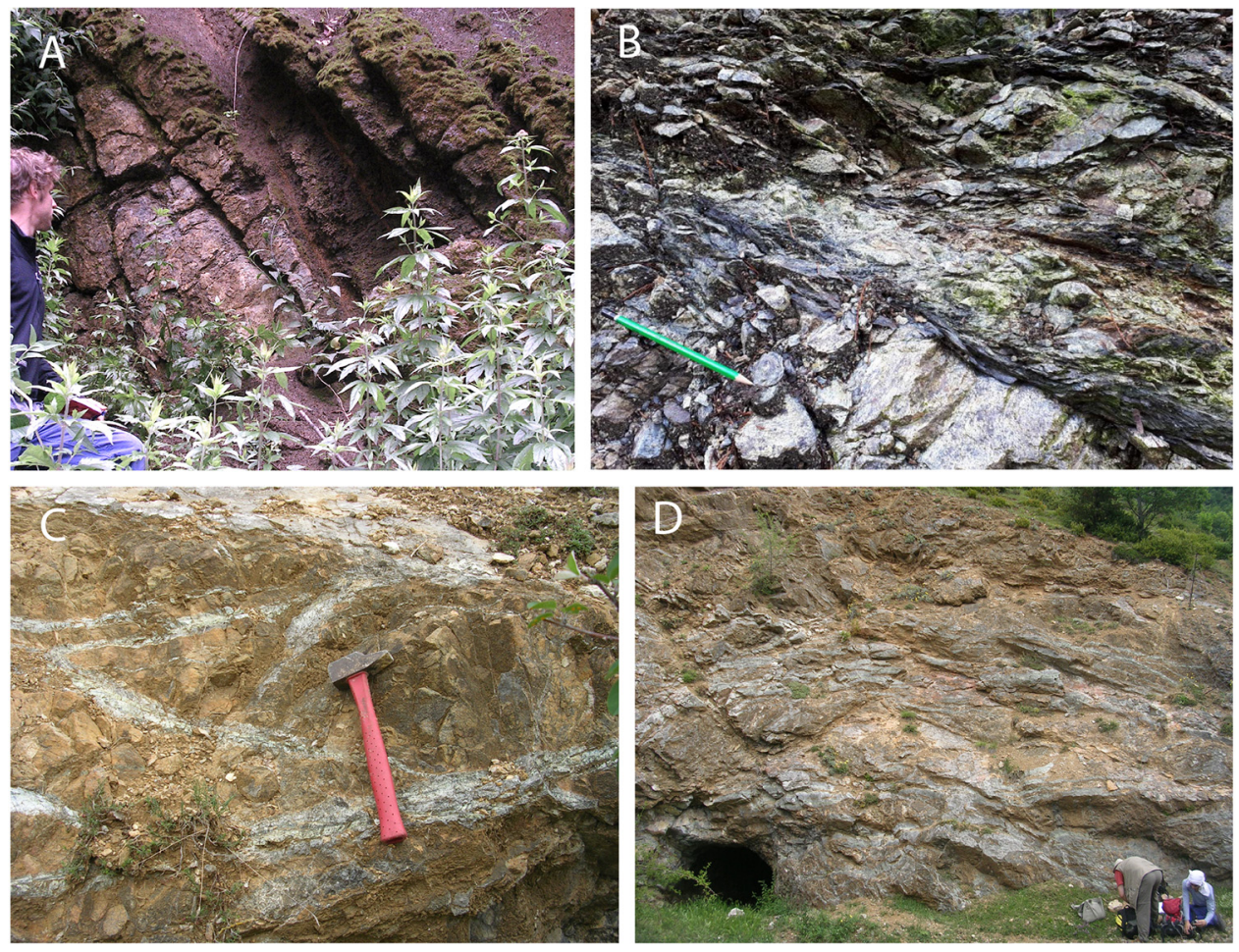

Fig. 11. Fabric of the crust-mantle detachment in various bodies along the NPZ. A. Moncaup (central Pyrenees). B. Montaut (eastern Chaînons Béarnais). C and D. Bestiac (central-eastern Pyrenees).

during its exhumation to upper crustal levels during the Albian-Cenomanian extension appears as an ubiquitous characteristic along the entire NPZ.

\subsubsection{Cover décollement}

The cover décollement is a $5-10 \mathrm{~m}$-thick deformed zone corresponding to the tectonic sole of the detached pre-rift Mesozoic cover (Fig. 10). It merges with the crust-mantle detachment at the northern tip of the Saraillé Paleozoic lenses where the continental crust has been completely extracted as a final result of the mid-Cretaceous rifting. Our field and microscopic study shows that the cover décollement appears composed of tectonic and metasomatic rocks belonging to three distinct types. (1) Where the Triassic material has been tectonically removed, it corresponds to metasomatic pyriterich, pink talc-chlorite schists forming successive tectonic lenses, up to a few meters thick, directly overlying the mantle rocks in the continuation of the crust-mantle detachment. Where Triassic elements still remain and can be easily recognized, the cover décollement can be divided into two types, as follows: (2) metasomatic yellow talc-rich calcschists with granular brown dolomites and oxidized pyrite grains; and (3) tectonic breccias of dominant orange-coloured dolomitic material including clasts of cellular dolomites, meta-ophites and fluid-inclusion bearing euhedral quartz of Keuper derivation in a matrix of thinly recrystallized chlorite and talc. In addition, the cover décollement also sampled a number of distinct Paleozoic lithologies.

By contrast with the damage zone of the crust-mantle detachment, deformation of the cover décollement is not localized, but is distributed between tectonic breccia corridors and anastomosed shear zones separating the lenses of metasomatic schists. It is important to conceive that this relatively thin fault-rock layer, as observed today, is the result of the tectonic disaggregation and fluid dissolution of a more than $1000 \mathrm{~m}$ thick initial layer of clays and evaporites representing huge volumes of Keuper deposits (James and Canérot, 1999; Saura et al., 2016; Orti et al., 2017; Soto et al., 2017). This conclusion concerns not only the Saraillé case, but also applies to the entire Chaînons Béarnais, and more broadly, to the entire NPZ as illustrated by some field examples in Figure 12 (Jammes et al., 2009; Lagabrielle et al., 2010). This specific behaviour of the Triassic sequence is probably the main parameter that controlled the mode of stretching of the passive Iberia margin because it allowed the crust to thin ductilely beneath the detached pre-rift cover, as early discussed in Clerc and Lagabrielle (2014) and numerically modelized by Duretz et al. (2019). The behaviour of salt layers during continental rifting has been addressed and discussed by numerous researchers since it controls major aspects of the final margin architecture (e.g. Rowan 2014, with references therein; Soto et al., 2017).

To sum up, displacement along the cover décollement during Albian-Cenomanian rifting locally led to the complete elision of the Triassic sequence with Dogger dolomites directly overlying the mantle rocks, as observed along the Saraillé fold (upper limb) and in the col d'Urdach section (see companion paper Lagabrielle et al., 2019). Therefore, the truncation, boudinage and cataclastic brecciation of the Triassic sequence compose the major structural pattern of the cover décollement at the regional scale. In addition, by place, the crystallization of metasomatic minerals from fluids circulating in this high-displacement contact zone led to 

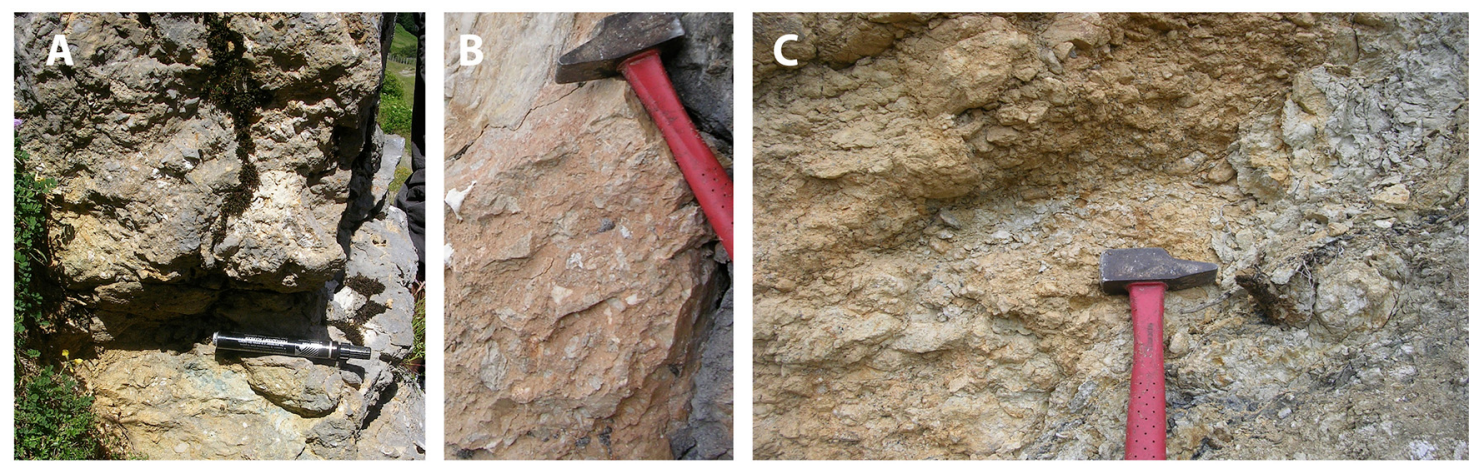

Fig. 12. Field aspect of the cover décollement along the NPZ. A. Tectonic breccia close to Etang de Lherz mantle body. B. Tectonic breccia against the St Barthélémy massif, close to the Bestiac lherzolite body. C. Tectonic breccia at the base of the pre-rift cover close to the MoncaupArguenos lherzolite body.

the formation of few meter-thick, newly crystallized fault rocks (e.g. pink talc-chlorite schists). This behaviour of the Upper Triassic layer controls important properties of the entire pre-rift sedimentary sequence. These properties, which include tectonic thinning, basal truncation and boudinage of the pre-rift sediments, have been gathered in the synthetic sketches of Figure 10.

\subsubsection{Differences between the Saraillé and Urdach massifs}

The Albian flysch of the Saraillé massif is strongly sheared and affected by a S0/S1 early foliation indicating that it has been buried under a thick flysch pile and suffered extensional deformation in relation with mantle exhumation processes during the mid- to Late Cretaceous times as depicted by Clerc et al. (2016). RAMAN spectroscopy of carbonaceous material (RSCM) indicates maximum temperatures of $250-350{ }^{\circ} \mathrm{C}$ in the Saraillé Albian flyschs with the highest values found close to the Saraillé lherzolite (Clerc, 2012; Clerc et al., 2015; Corre, 2017). This strongly differs from the Urdach massif setting. In this massif, the mantle rocks were exposed to the seafloor during the Late Albian times and the temperatures of the flyschs are colder $\left(250^{\circ} \mathrm{C} \max \right)$ (Corre, 2017). Conceptual cross-sections of the distal margin in Figure 11 are designed to highlight these differences. They illustrate a two-steps scenario for the evolution of the distal margin during a $20 \mathrm{Myr}$ time span, from 108 to $88 \mathrm{Ma}$ (Albian to Turonian). This scenario is based on one hypothesis and one statement. (i) Our hypothesis is that the region of active tectonics is not steady-state but moves continentward. As a result, when extension initiates in the Saraillé region, it already ceased in the Urdach area. (ii) Our statement is that extension is active during flysch sedimentation. As a result, extension in the Saraillé region occurs under a cover of recently deposited Upper Albian and Cenomanian flyschs. Finally, sedimentary burial and thermal blanketing effect over the Saraillé area allow the preservation of greenschist facies conditions at the base of the syn-rift flysch pile, in the pre-rift sediments, and in the hyper-stretched crust. Such moderate thermal conditions favour a ductile mode of thinning in the crustal basement of basin regions suffering the highest subsidence rates.

\subsection{Serpentinization of the Saraillé and Chaînons Béarnais mantle bodies: insights on the processes of peridotite hydration during (the last stages of) rifting}

Serpentinites result from the hydration of ultramafic rocks at low $\left(100^{\circ} \mathrm{C}\right)$ to intermediate $\left(500^{\circ} \mathrm{C} \max \right)$ temperature. Pervasive serpentinization of mantle rocks during passive margin formation is an ubiquitous process that involves a considerable volume of seawater (Wenner and Taylor, 1971; Evans, 2004). The Saraillé peridotites show a 50 to $100 \%$ serpentinization with rare relicts of primary minerals (Gaudichet, 1974). Despite this high rate of serpentinization, pristine high temperature mantle structures such as the pyroxenitic layering can be traced along tens of meters without crossing any shear zone or fault in the core of the massif. Our observation of the internal fabric of the Saraille body confirms that the early pervasive serpentinization is not associated with deforming zones. Static pervasive serpentinization is also documented in the core of the nearby Urdach massif (see companion paper Lagabrielle et al., 2019). In marked contrast, the Turon de la Tecouére massif located some tens of $\mathrm{km}$ eastward, is entirely composed of highly deformed lherzolites that suffered progressive mylonitization associated with the transformation from spinel- to plagioclase-bearing assemblages in the range of $800-600^{\circ} \mathrm{C}$ with pressure less than 800-600 Mpa, corresponding to depths of 30-20 km (Vissers et al., 1997). These peridotites are remarkably fresh and show only very local serpentinization along discrete planes. We thus conclude that: (1) serpentinization of the Chaînons Béarnais bodies is not necessarily linked to deformation zones in the mantle; (2) some medium-temperature $\left(>500^{\circ} \mathrm{C}\right)$ deforming zones escaped hydration and serpentinization during the margin evolution and; (3) these medium-T deforming zones are not ubiquitous in the Chaînons Béarnais peridotites and preserve undeformed mantle volumes between them.

The mylonitization mechanism of the Turon de la Técouère peridotites implies high-stress dislocation creep and dynamic recrystallization followed by incipient brittle behaviour in shear zones in relation with uplift and cooling (Vissers et al., 1997). This result is consistent with temperature estimates by Fabriès et al. (1991), who concluded that mylonitic deformation in the western Pyrenean peridotites occurred during 

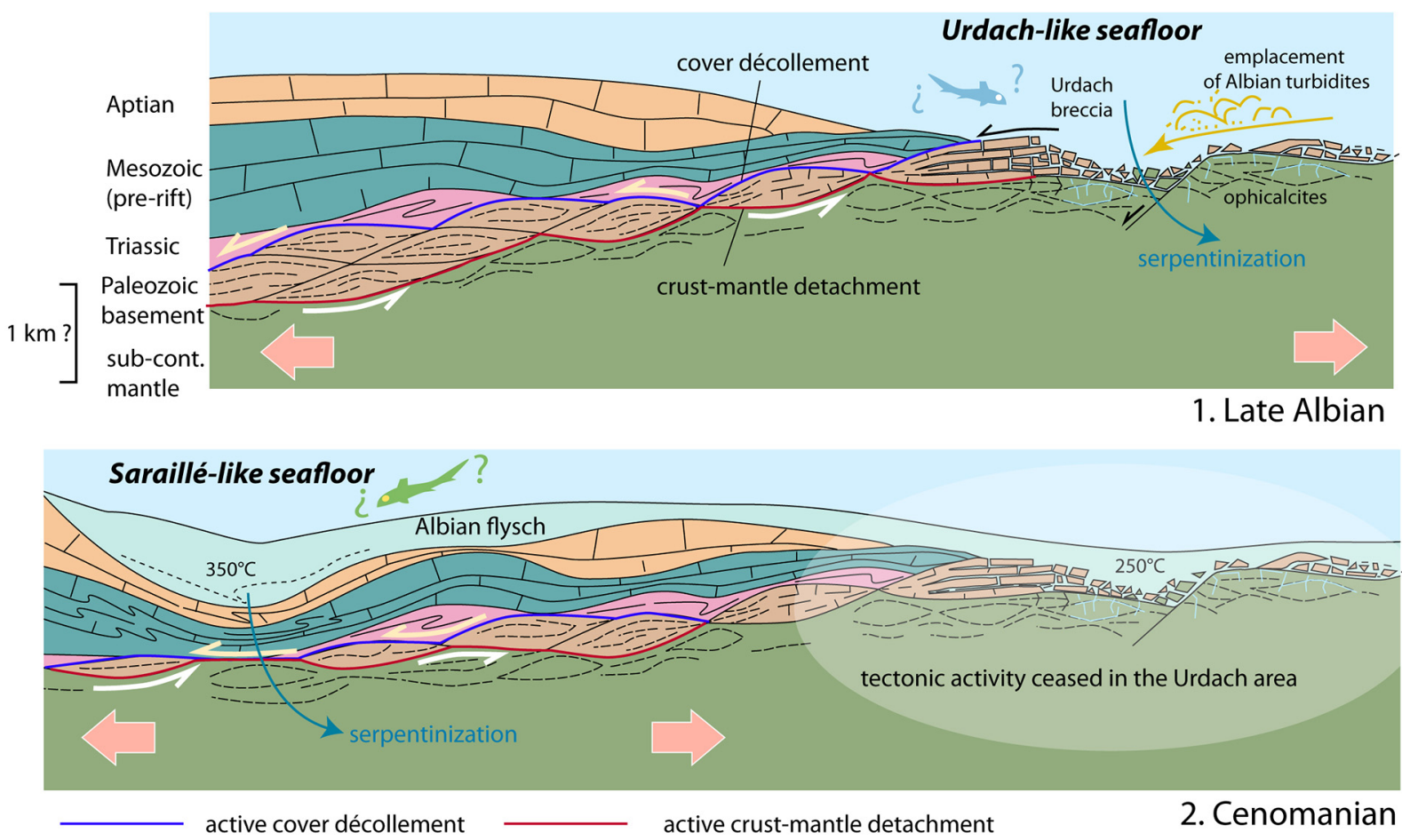

Fig. 13. A two-steps evolution of the North Iberia distal margin from geological constraints provided by the Urdach and Saraillé mantle bodies and adjacent formations (see companion paper Lagabrielle et al., 2019, for data relative to the Urdach massif). Syn-metamorphic extensional deformation continued in the Saraillé area (beneath a cover of Albian-Cenomanian flysch) once extension ceased in the Urdach area (See Clerc et al., 2016 for more details of such evolution).

cooling from temperatures in the range of $950{ }^{\circ} \mathrm{C}$ down to 600 $650^{\circ} \mathrm{C}$. These discrete mylonite zones have thus accommodated the very early stages of the peridotite uplift and were active prior to extensive serpentinization of the subcontinental mantle margin.

In the Chaînons Béarnais, serpentinization is pervasive in mantle bodies that were exposed to the seafloor (Urdach), as well as in bodies associated with a drastically thinned crust, including its pre-rift cover (Saraillé). By contrast, the thickest and non-attenuated pre-rift sequence of the western NPZ, the Mail Arrouy unit, overlies the non-serpentinized Turon de la Técouère lherzolites associated with thin Paleozoic remnants. Therefore, a link may exist between high serpentinization rate and drastic tectonic attenuation of the pre-rift sedimentary pile. However, this hypothesis remains speculative since we lack information relative to the thickness of the basement rocks at the scale of the entire Chaînons Béarnais area during the final mantle exhumation stage (Fig. 13).

During the Cretaceous rifting event, the medium-T shear zones observed in the Turon de Técouère body probably connected to the precursors of the crust-mantle detachment and progressively focused the relative displacements between the peridotites and the Paleozoic basement. Unfortunately, due to extremely poor constraints from the small mantle bodies widespread in the Chaînons Béarnais, we lack information on the way these connections were made possible. We may only infer that drastic changes in the deforming system occurred when seawater got access to the mantle, allowing peridotite serpentinization and subsequent drastic weakening of the uppermost mantle.

According to the volumetric importance of the serpentinization in the Saraille and Urdach bodies, the hydrothermal system that drove the pervasive mantle hydration has to be considered at the scale of the entire margin. All hydration models view seawater as a fluid entering the input branches of the serpentinization cells. In the conceptual margin reconstruction of Figure 14, we infer that seawater enters the passive margin exhumation system through two possible and nonexclusive pathways.

A first pathway is represented by the main faults of the necking domain. In a conceptual model, Guillot et al. (2015), propose that these faults offset the entire continental crust, offering direct access to the subcontinental mantle. The Albian-Cenomanian Trimouns fault in the St Barthelemy massif (central Pyrenees; Schärer et al., 1999) could represent an example of such a major fault. A similar plumbing system is also well established in the case of the Alpine Tethys paleomargins (Pinto et al., 2015). The Guillot et al. (2015)'s model implies a plumbing connection between the brittle crust and the crust-mantle detachment throughout volumes of crust that behave ductilely during mantle exhumation. This connection is difficult to conceive theoretically and would imply massive hydration of the ductilely deformed Paleozoic rocks, a process which is not supported by our data (Asti et al., 2019).

The second pathway is located in the distal margin domain where the detached pre-rift cover and underlying Paleozoic 


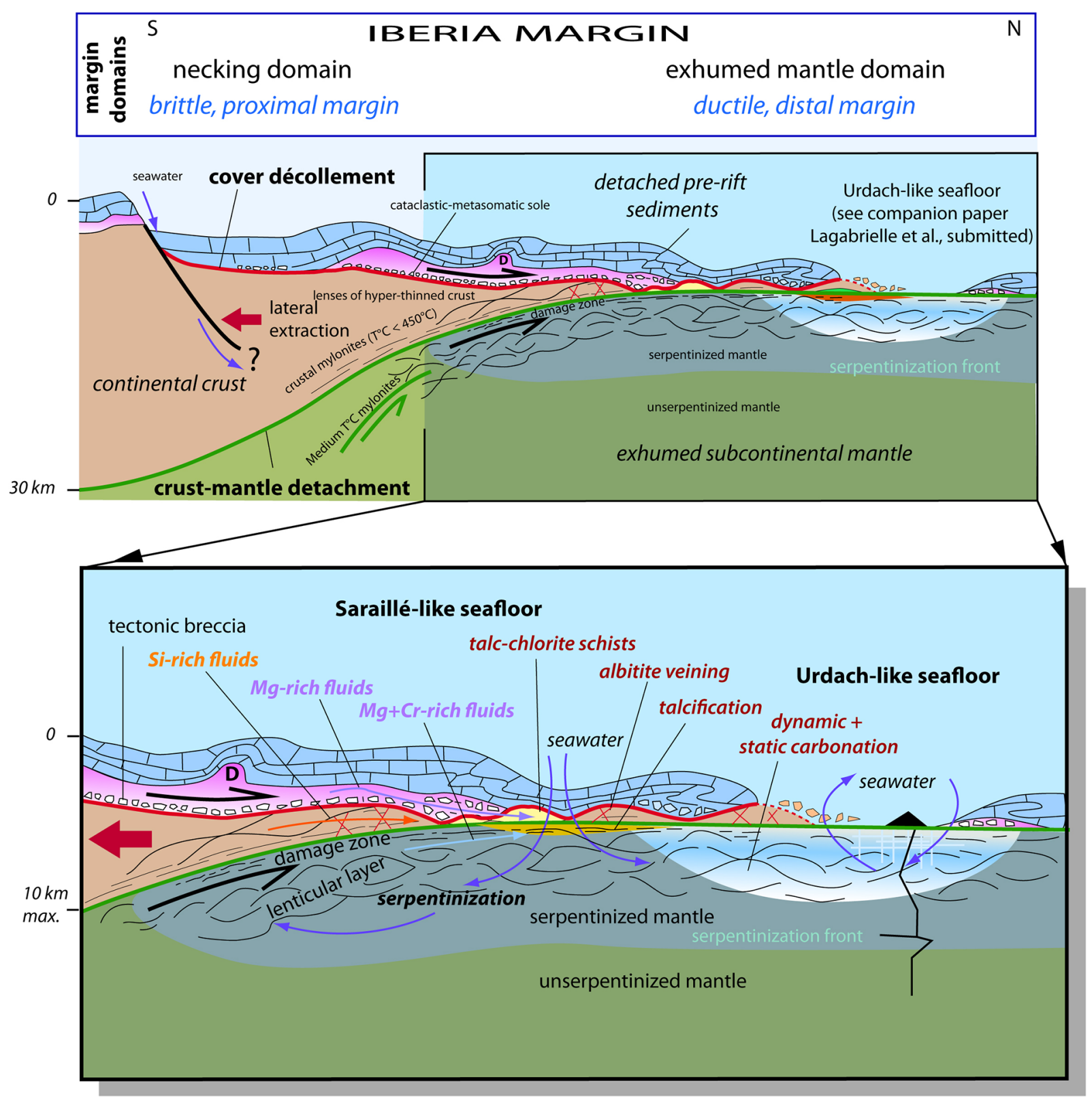

Fig. 14. A reconstruction of the North Iberia distal margin with emphasis on fluid pathways in the crust-mantle detachment and cover décollement as reconstructed from geological and mineralogical studies in the Saraillé massif (detailed comments in text).

basement suffered intense necking (Saraillé) culminating in the exhumed mantle domain where peridotites are exposed directly to the seafloor (Urdach) (Fig. 13). It is noteworthy from the Saraille example that serpentinization of subcontinental mantle may occur indeed under a thin layer of ductilely deformed crustal rocks. Finally, as early proposed, we may conclude that seawater access to the uplifting mantle is likely facilitated through disconnected windows corresponding to regions of attenuated pre-rift sequences and hyper-thinned Paleozoic basement units.

The discussion above focuses on the strongly sheared rocks of the fault zones. However, some poorly deformed ultramafic rocks underwent carbonation and/or talcification preserving their internal pristine mantle texture (e.g. samples BCOR107, BCOR108 and BCOR110). This implies that fluid circulation is not restricted to the high strain zone of the crust-mantle detachment. Metasomatic fluids may circulate pervasively out of the main pathways, through undeformed mantle volumes. Therefore, we assume that the base of the serpentinized mantle (the serpentinization front) progressively extended toward deeper levels (Fig. 14). This front might correspond to a relatively sharp boundary and to a major rheological limit that will be used as a décollement level during the compressional Pyrenean phase. 


\subsection{Fluid-rock interaction along the crust-mantle detachment and cover décollement}

In the following, we discuss the significance of the metasomatic assemblages of the studied fault zones and we address the question of the origin and evolution of their parental fluids.

\subsubsection{Crust-mantle detachment}

Strong metasomatic transformations along the crust-mantle detachment of the Saraillé massif are documented by serpentinization, carbonation (either calcitic or dolomitic), talcification, chloritization and abundant pyrite precipitation. The presence of dolomite during mantle carbonation is reported from the alpine Chenaillet ophiolitic massif where it indicates low carbonation rates (Lafay et al., 2017). Along the Saraillé crust-mantle detachment, we can distinguish a carbonate-free and a carbonate-bearing talcification (Fig. 10). The first one concentrates under Paleozoic units and the second one develops beneath the detached pre-rift sediments. This might reflect difference in fluid composition and the direct influence of the lithology of the hanging wall providing Si-bearing fluids either enriched or depleted in $\mathrm{Ca}$. In addition, the $\mathrm{Cr}$ content of chlorites from the carbonated reactional rocks is the indisputable evidence of their ultramafic derivation.

Talc crystallization in fault zones results from the reaction of ultramafic rocks with silica-saturated hydrothermal fluids (Boschi et al., 2006; Moore and Lockner, 2008). Therefore, talcification of the damage zone of the Saraille lherzolites requires either extensive $\mathrm{Mg}$-leaching or the circulation of $\mathrm{Si}$ bearing-fluids in this Mg-rich medium. Such fluids can be produced by the serpentinization reactions and may be a consequence of the syn-kinematic serpentinization-carbonation we observe. However, in the slow-spreading ridges settings, talcification is not a characteristic of an ultramaficdominated environment, as reported from the Lost City field and from the South West Indian Ridge. Rather, these environments are devoid of talc precipitates (Sauter et al., 2013; Rouméjon et al., 2015). Talcification generally implies a nearby, more silica-rich source able to provide Si-rich fluids as exemplified by the Atlantis site (Bach et al., 2004; Rouméjon et al., 2018). Our data from the crustal lenses welded on the Saraillé mantle body indicate that fluids circulating in the deforming crust participated in the crystallization of numerous albitite veinlets. Concomitant extraction of silica from this basement may provide Si required for talcification. Therefore, the crustal lenses $v s$. mantle lithological duality likely worked as source and sink of $\mathrm{Si}$, respectively, by means of fluids convective cells in producing the albitization-talcification metasomatic transformations. In addition to a source of $\mathrm{Si}$, a source of $\mathrm{S}$ and $\mathrm{Fe}$ (widespread pyritization) is required for the metasomatizing fluid. This suggests the involvement of seawater $+/-$ Triassic derived fluids together with a possible sulfate-sufide reduction process.

\subsubsection{Cover décollement}

The complete metasomatic assemblage found in the Saraillé cover décollement includes: talc, Cr-rich or Cr-free chlorite, albite, calcite, dolomite, white micas, magnesite (with orthoclase inclusions), green amphiboles (in meta-ophites), typical of greenschist facies conditions, and almost ubiquitous pyrite. Similar assemblages are described along the NPZ and are ascribed to the Cretaceous Pyrenean metamorphic event (Ravier, 1959; Albarède and Michard-Vitrac, 1978; Bernus-Maury, 1984; Golberg and Leyreloup, 1990; Clerc et al., 2015). Paleotemperatures deduced from clinochlore compositions indicate conditions of $200-350^{\circ} \mathrm{C}$ during metasomatism in the Saraille cover décollement (Corre et al., 2018), in agreement with previous estimates of $250-350^{\circ} \mathrm{C}$ by Fortané et al. (1986). RSCM yielded maximum temperatures of $250-350^{\circ} \mathrm{C}$ in the Albian flyschs (Clerc et al., 2015; Corre et al., in prep.). This confirms previous estimates based on metamorphic assemblages of neoformed muscovite, chlorite and albite by Gaudichet (1974), indicating greenschist facies conditions in the whole Mesozoic cover of the Sarrance anticline (including the Albian flyschs) and agrees with the re-equilibration temperature obtained on ophicalcitic veins in the Urdach massif, using clumped isotopes (DeFelipe et al., 2017).

As shown from microscopic observations, the Saraillé cover décollement assemblage displays two types of talcdolomite intergrowths. Besides a syn-kinematic generation, another one is static and made of cogenetic acicular talc and large dolomite poikiloblasts. A two-phased metasomatism is possible that would account for that observation, but the simplest interpretation calls for successive gliding steps along the cover décollement with temperature inertia after the main thermal crisis. It is well established indeed that a long-lived thermal anomaly lasted after the extensional climax in the Mauléon basin during the Late Cretaceous allowing synkinematic (Vacherat et al., 2014; Bosch et al., 2016).

The metasomatic assemblage in the Saraillé cover décollement is dominated by the crystallization of dolomite and talc-chlorite association with minor calcite and quartz. The overall dolomitization and the large amount of euhedral dolomites in the newly-formed assemblage favors a local origin form the metasomatic fluids by mobilization of the in situ Triassic and nearby Jurassic dolostones. However additional contribution of mantle-derived fluids is indicated by the presence of $\mathrm{Cr}$-bearing clinochlores at various localities. The fluid-rock interactions inside the Saraillé cover décollement and the overlying Mesozoic cover have been previously studied earlier through analyses of fluid inclusions in various types of calcite and quartz veins, revealing the dominant effect of fluids from Triassic evaporites (Corre et al., 2018). Therefore, the Mg-rich metasomatism that characterizes the Saraillé cover décollement certainly results from at least two sources: (i) dissolution of local Triassic and nearby Jurassic dolomites and (ii) serpentinization of the mantle rocks. These two types of fluids may interact with fluids deriving directly from the Triassic evaporites undergoing active deformation (primary brines) (Corre et al., 2018). These various fluid pathways have been compiled and simply illustrated on the distal margin reconstruction of Figure 14.

Our interpretation of the origin and main pathways of the cover décollement Saraillé fluids can be compared to the results obtained from the study of the Urdach cover décollement along the "ball trap" section (see companion paper Lagabrielle et al., 2019). The Urdach cover décollement is a preferential pathway for serpentinization and carbonation-related fluids during mantle exhumation, triggering the co-crystallization of serpentine and 
calcite and involving large amount of seawater. Other types of fluids are recognized, notably continental-derived fluids enriched in Si and $\mathrm{K}$ leading to the formation of listvenites. Like in the Saraillé, the presence of metasomatic rocks and cataclastic breccias involving Triassic material (ophites, dolomites) in the Urdach cover-décollement highlights the deep transformation that occurred in the sole of the detached pre-rift cover during its displacement along this fault.

\section{Conclusions}

Our geological investigations in the Saraillé ultramafic massif of the western Pyrenees focused on two extensional shear zones that controlled the exhumation of the subcontinental mantle beneath the Albian-Cenomanian basins of the NPZ. The crust-mantle detachment is the deepest one and separates the serpentinized lherzolites from the strongly thinned Paleozoic rocks. The cover décollement is the shallowest one and runs at the base of the detached pre-rift Mesozoic metasedimentary cover. Both fault zones merge where the thickness of the Variscan basement has been reduced to zero following extreme crustal stretching. Based on the results exposed in this article, we highlight the following conclusions:

- the crust-mantle detachment is a 50 to $100 \mathrm{~m}$ thick shear zone with a basal lenticular layer of serpentinized mantle phacoids separated by anastomozing shear zones and a thin upper damage zone of strongly sheared talc-chlorite schists displaying pyrite concentrations. Serpentinization was active during displacement in the lenticular layer with a combination of layer-parallel shear and layer perpendicular shortening. This layer appears as an active pathway for the serpentization fluids. Mantle rocks in the crust-mantle detachment exhibit evidence of local pervasive carbonation with silicates replaced in situ by calcite and/or dolomite associated with Cr-rich chlorites. Displacement and deformation along both the lenticular layer and the damage zone occurred in $\mathrm{P}-\mathrm{T}$ conditions of the greenschist facies $\left(T<500^{\circ} \mathrm{C}\right)$. Talcification and mineralization of the damage zone requires the circulation of hydrothermal fluids with high $\mathrm{Si}, \mathrm{Mg}-\mathrm{Fe}$, and $\mathrm{S}$ concentrations. These fluids may originate from the continental crust undergoing active deformation and albitization, with a possible contribution of Triassic-derived fluids. The progressive development of hydrated minerals in the uppermost exhumed mantle (talc and chlorites) is critical to the mechanical weakening of the damage zone and helps focusing displacements along this sharp boundary;

- the cover décollement is a $5-10 \mathrm{~m}$ thick fault zone corresponding to the tectonic sole of the pre-rift detached cover. It results from the brecciation of upper Triassic layers and their metasomatic alteration by a multi-component fluid ending with static crystallization of dol + talc $+\mathrm{chl}+$ pyr, also in the greenschist facies conditions. Important features are the general dolomitization along the cover décollement, thus recording circulation of $\mathrm{Mg}$-saturated fluids;

- we highlight that mantle serpentinization in the Saraillé massif occurred under a thin cover of strongly attenuated continental crust. This strongly suggests that mantle exposure to the sea-floor is not a necessary condition for pervasive serpentinization. Moreover, static serpentinization of large undeformed volumes of the ultramafic body shows that this process does not occur only along extensional structures acting as efficient fluid pathways, but also by hydration of the passively exhuming mantle domains that remain undeformed during exhumation. Comparison with the Turon de la Técouère massif suggests that serpentinization of the mantle is not pervasive when the pre-rift sedimentary cover is not drastically attenuated.

Finally, this study provides geological constraints showing that the distal Iberia margin encompassed: (1) syn-rift kmscale cover décollement; (2) ductile thinning of the crustal basement and; (3) mantle exhumation in the distal domain. It shows that the presence of a thick pre-rift evaporitic layer (Keuper) at the base of a pre-rift sedimentary pile played an active role in determining the style of mantle exhumation in the western Pyrenean realm. This represents a new contribution to our understanding of the evolution of continental passive margins with pre-rift salt (e.g. Rowan, 2014) and notably reveals a non-suspected relationship between evaporite-rich pre-rift series and the deformation mode at the lithospheric-scale. The temperature conditions of the deformation in the Saraillé crustal basement and in the pre-rift sediments are not as high as those reported from the Central and Eastern NPZ. These latter portions of the NPZ are characterized by high thermal paleo-geotherms with Tmax in Mesozoic carbonates reaching almost $600^{\circ} \mathrm{C}$ (Golberg and Leyreloup, 1990; Vauchez et al., 2013; Clerc et al., 2015). As a consequence, ductile deformation in the upper crustal levels might develop even in rift regions characterized by moderate geotherms. It thus appears that the key-factor controlling the NPZ mode of crustal stretching is the decoupling of the detached Mesozoic pre-rift along the thick Triassic clays and evaporites layer acting as a thermal blanket in the basin center, with additional sedimentary burial beneath the syn-rift series. Both processes allow the preservation of greenschist facies conditions in the pre-rift sedimentary pile and in the hyper-stretched crust.

\section{Supplementary Material}

Figure S1: Microscopic aspects of the crust-mantle detachment and cover décollement in the Saraillé massif.

Figure S2: Microscopic aspects of the Saraillé talcified mantle rock from the crust-mantle detachment (sample SAR2a).

Figure S3: Microscopic aspects of the cover décollement in the western part of Saraillé massif.

Figure S4: Mineralogical transformations of the Upper Triassic material in the cover décollement of the Saraillé massif: microscopic aspects (part 1).

Figure S5: Mineralogical transformations of the Upper Triassic material in the cover décollement of the Saraillé massif: microscopic aspects (part 2).

Figure S6: Mineralogical transformations of the Upper Triassic material in the cover décollement of the Saraillé massif: microscopic aspects (part 3).

Tables 1-5: Microprobe mineralogical analyses.

The Supplementary Material is available at http://www.bsgf.fr/ 10.1051/bsgf/2019013/olm. 
Acknowledgements. This study is the result of 10 years of research in the NPZ and benefited from grants from various programs that are thoroughly acknowledged here. YL, PL and BC were founded by the Référentiel Géologique de la France (RGF), BRGM. They are indebted to Thierry Baudin, head of RGF program, for his confidence allowing a 4 years field and laboratory full research period through $\mathrm{BC} \mathrm{PhD}$ and Master2 thesis. Additional grants were attributed to RA from the OROGEN, INSU/CNRS-BRGM-Total program allowing focus on the Variscan material. ANR Pyramid and ANR Pyrope also provided some funds that were used for field work. We thank Jessica Anglande for assistance at the "Microsonde Ouest, Plouzané", and Bernard Azambre for his help in microscopic determination of volcanic and metamorphic material. A few persons from the villages nearby Saraillé and Urdach helped our team for lodging: we acknowledge Françoise Pape and Jean-Eric Rose for welcoming us in the Chaînons Béarnais. YL wish to thank especially Loïc Brugalais and Orthofiga, Vern/Seiche, for making field work possible. We thank reviewers Olivier Merle, Geoffroy Mohn and the associate-editor Romain Augier for their constructive remarks that helped greatly improve this manuscript.

\section{References}

Albarède F, Michard-Vitrac A. 1978. Age and significance of the North Pyrenean metamorphism. Earth and Planetary Science Letters 40: 327-332. DOI: 10.1016/0012-821X(78)90157-7.

Andersen TB, Corfu F, Labrousse L, Osmundsen P-T. 2012. Evidence for hyperextension along the pre-Caledonian margin of Baltica. Journal of the Geological Society (London) 169: 601-612. DOI: 10.1144/0016-76492012-011.

Asti R, Lagabrielle Y, Fourcade S, Corre B, Monié P. 2019. How do continents deform during mantle exhumation? Insights from the northern Iberia inverted paleo-passive margin, western Pyrenees (France). Tectonics 38: 1666-1693. DOI: 10.1029/2018TC005428.

Bach W, Garrido CJ, Paulick H, Harvey J, Rosner M. 2004. Seawaterperidotite interactions: First insights from ODP Leg 209, MAR $15^{\circ}$ N. Geochemistry Geophysics Geosystems 5: Q09f26. DOI: 10.1029/2004GC000744.

Bernus-Maury C. 1984. Étude des paragéneses caractéristiques du métamorphisme mésozoïque dans la partie orientale des Pyrénées. Unpublished Thesis, Paris, $253 \mathrm{p}$.

Bosch G, Teixell A, Jolivet M, Labaume P, Stockli D, Domènech M, et al. 2016. Record of Eocene-Miocene thrusting in the western Axial Zone and Chaînons Béarnais (west-central Pyrenees) revealed by multi-method thermochronology. Comptes Rendus Geoscience 348: 246-256. DOI: 10.1016/j.crte.2016.01.001.

Boschi C, Früh-Green GL, Delacour A, Karson JA, Kelley DS. 2006. Mass transfer and fluid flow during detachment faulting and development of an oceanic core complex, Atlantis Massif (MAR 30 N). Geochem. Geophys. Geosystems 7: 129-140.

Canérot J. 2017. The pull apart-type Tardets-Mauléon Basin, a key to understand the formation of the Pyrenees. Bulletin Société géologique de France 188: 35. DOI: 10.1051/bsgf/2017198.

Canérot J, Delavaux F. 1986. Tectonic and sedimentation on the north Iberian margin, Chaînons Béarnais south Pyrenean zone (Pyrenees bascobéarnaises) - New data about the signification of the lherzolites in the Saraillé area. C R Acad Sci Ser II 302(15): 951-956.

Canérot J, Peybernes B, Cizsak R. 1978. Présence d'une marge méridionale à l'emplacement des Chaînons Béarnais (Pyrénées basco-béarnaises). Bull Soc geol Fr 7(20): 673-676.
Casteras M, Canérot J, Paris J-P, Tisin D, Azambre B, Alimen H. 1970. Carte géol. France (1/50 000), feuille Oloron-Sainte-Marie (1051). Orléans : BRGM.

Chew M, Van Staal CR. 2014. The ocean-continent transition zones along the Appalachian-Caledonian margin of Laurentia: Examples of large-scale hyperextension during the opening of the Iapetus Ocean. Geosci Can 41. DOI: 10.12789/geocanj.2014.41.040.

Choukroune P, ECORS team. 1989. The Ecors deep seismic profile reflection data and the overall structure of an orogenic belt. Tectonics 8: 23-39.

Choukroune P, Mattauer M. 1978. Tectonique des plaques et Pyrénées : sur le fonctionnement de la faille transformante nordPyrénéenne; comparaisons avec les modèles actuels. Bulletin de la société géologique de France 20: 689-700.

Clerc C. 2012. Évolution structurale du domaine Nord-Pyrénéen au Crétacé. Amincissement crustal extrême et thermicité élevée: un analogue pour les marges passives. PhD Thesis (Unpublished), ENS Université Paris VI.

Clerc C, Lagabrielle Y. 2014. Thermal control on the modes of crustal thinning leading to mantle exhumation: Insights from the Cretaceous Pyrenean hot paleomargins. Tectonics 33(7): 1340-1359.

Clerc C, Lahfid A, Monié P, Lagabrielle Y, Chopin C, Poujol M, et al. 2015. High-temperature metamorphism during extreme thinning of the continental crust: A reappraisal of the north Pyrenean passive paleomargin. Solid Earth 6: 643-668.

Clerc C, Lagabrielle Y, Labaume P, Ringenbach J-C, Vauchez A, Nalpas $\mathrm{T}$, et al. 2016. Basement-Cover decoupling and progressive exhumation of metamorphic sediments at hot rifted margin. Insights from the northeastern Pyrenean analog. Tectonophysics 686: 82-97.

Corre B. 2017. La bordure nord de la plaque ibérique à l'AlboCénomanien. Architecture d'une marge passive de type ductile (Chaînons Béarnais, Pyrénées Occidentales). Thesis (Unpublished), Rennes 1 University, France.

Corre B, Lagabrielle Y, Labaume P, Fourcade S, Clerc C, Ballevre M. 2016. Deformation associated with mantle exhumation in a distal, hot passive margin environment: New constraints from the Saraillé Massif (Chaînons Béarnais, North-Pyrenean Zone). Compt Rendus Geosci 348: 279-289.

Corre B, Boulvais P, Boiron MC, Lagabrielle Y, Marasi L, Clerc C. 2018. Fluid circulations in response to mantle exhumation at the passive margin setting in the north Pyrenean zone, France. Mineralogy and Petrology. DOI: 10.1007/s00710-018-0559-x.

Debroas E-J. 1978. Évolution de la fosse du flysch ardoisier de l'Albien supérieur au Sénonien inférieur (zone interne métamorphique des Pyrénées navarro-languedociennes). Bull Soc géol Fr 20: 639-648.

Debroas EJ, Canérot J, Bilotte M. 2010. Les Brèches d'Urdach, témoins de l'exhumation du manteau pyrénéen dans un escarpement de faille Vraconnien-Cénomanien inférieur (zone nord-pyrénéenne, Pyrénées-Atlantiques, France). Géol Fr 2: 53-63.

DeFelipe I, Pedreira D, Pulgar JA, Iriarte E, Mendia M. 2017. Mantle exhumation and metamorphism in the Basque-Cantabrian Basin (N Spain): Stable and clumped isotope analysis in carbonates and comparison with ophicalcites in the North-Pyrenean Zone (Urdach and Lherz). Geochem Geophys Geosyst 18(2): 631-652.

Ducoux M, Jolivet L, Cagnard F, Gumiaux C, Baudin T, Masini E, et al. The Nappe des Marbres unit of the Basque-Cantabrian basin: The tectono-thermal evolution of a fossil hyperextended rift basin. Tectonics, in press.

Duretz T, Asti R, Lagabrielle Y, Brun JP, Jourdon A, Clerc C, et al. 2019. Numerical modelling of Cretaceous Pyrenean Rifting: The interaction between mantle exhumation and syn-rift salt tectonics. Basin Research 2019: 1-16. DOI: 10.1111/bre.12389. 
Evans BW. 2004. The serpentinite multisystem revisited: Chrysotile is metastable. Int Geol Rev 46: 479-506.

Fabriès J, Lorand J-P, Bodinier J-L, Dupuy C. 1991. Evolution of the upper mantle beneath the Pyrenees: Evidence from orogenic spinel lherzolite massifs. J Petrol, sp. volume "Orogenic lherzolites and mantle processes", pp. 55-76.

Fabriès J, Lorand J-P, Bodinier J-L. 1998. Petrogenetic evolution of orogenic lherzolite massifs in the central and western Pyrenees. Tectonophysics 292: 145-167.

Fortané A, Duée G, Lagabrielle Y, Coutelle A. 1986. Lherzolites and the Western "Chaînons Béarnais" (French Pyrénées): Structural and paleogeographical pattern. Tectonophysics 129: 81-98.

Gaudichet A. 1974. Étude pétrographique des lherzolites de la région d'Oloron-Ste Marie (Pyrénées Atlantiques). Thesis (Unpubl.), Univ. of Paris VI.

Golberg J-M, Leyreloup A-F. 1990. High temperature-low pressure Cretaceous metamorphism related to crustal thinning (Eastern North Pyrenean Zone, France). Contributions to Mineralogy and Petrology 104(2): 194-207. DOI: 10.1007/BF00306443.

Guillot S, Schwartz S, Agard P, Renard B, Prigent C. 2015. Tectonic significance of serpentinites. Tectonophysics. DOI: 10.1016/j. tecto.2015.01.020.

Jakob J, Andersen TB, Kjøll HJ. 2019. A review and revision of the rift inherited architecture of the South and Central Scandinavian Caledonides - a magma-poor to magma-rich transition and the significance of reactivation of rift-inheritance during the Caledonian Orogeny. Earth Science Review. DOI: 10.1016/j.ear scirev.2019.01.004.

James V, Canérot J. 1999. Diapirisme et structuration post-triasique des Pyrénées occidentales et de l'Aquitaine méridionale (France). Eclogae geol Helv 92: 63-72.

Jammes S, Manatschal G, Lavier LL, Masini E. 2009. Tectonosedimentary evolution related to extreme crustal thinning ahead of a propagating ocean: Example of the western Pyrenees. Tectonics 28 (4). DOI: 10.1029/2008TC002406.

Lafay R, Baumgartner PL, Schwartz S, Picazo S, Montes-Hernandez G, Torsten V. 2017. Petrologic and stable isotopic studies of a fossil hydrothermal system in ultramafic environment (Chenaillet ophicalcites, Western Alps, France): Processes of carbonate cementation. Lithos V(294-295): 319-338. DOI: 10.1016/j. lithos.2017.10.006.

Lagabrielle Y, Bodinier JL. 2008. Submarine reworking of exhumed subcontinental mantle rocks: Field evidence from the Lherz peridotites, French Pyrenees. Terra Nova 20(1): 11-21. DOI: 10.1111/j.1365-3121.2007.00781.

Lagabrielle Y, Labaume P, de Saint Blanquat M. 2010. Mantle exhumation, crustal denudation, and gravity tectonics during Cretaceous rifting in the Pyrenean realm (SW Europe): Insights from the geological setting of the lherzolite bodies. Tectonics 29(4): 1-26.

Lagabrielle Y, Clerc C, Vauchez A, Lahfid A, Labaume P, Azambre B, et al. 2016. Very high geothermal gradient during mantle exhumation recorded in mylonitic marbles and carbonate breccias from a Mesozoic Pyrenean palaeomargin (Lherz area, North Pyrenean Zone, France). Compt Rendus Geosci 348: 257-267.

Lagabrielle Y, Asti R, Fourcade S, Corre B, Poujol M, Uzel J, et al. 2019. Mantle exhumation at magma-poor passive continental margins. Part I. 3D architecture and metasomatic evolution of a fossil exhumed mantle domain (Urdach lherzolite, northwestern Pyrenees, France). BSGF-Earth Sciences Bulletin 190: 8. DOI: $10.1051 / \mathrm{bsgf} / 2019007$.

Lavier L, Manatschal G. 2006. A mechanism to thin the continental lithosphere at magma-poor margins. Nature. DOI: 10.1038/ nature 04608 .
Le Pichon X, Bonnin J, Sibuet JC. 1970. La faille nord-pyrénéenne : faille transformante liée à l'ouverture du Golfe de Gascogne. $C R$ Acad Sc (Paris) 271(série D): 1941-1944.

Le Roux V, Bodinier J-L, Tommasi A, Alard O, Dautria J-M, Vauchez A, et al. 2007. The Lherz spinel lherzolite: Refertilized rather than pristine mantle. Earth and Planetary Science Letters 259: 599-612.

Lemoine M, Boillot G, Tricart P. 1987. Utramafic and grabbroic ocena floor of the Ligurian Tethys (Alps, Corsica, Apennines): In search of a genetic model. Geology 15: 622-625.

Manatschal G. 2004. New models for evolution of magma-poor rifted margins based on a review of data and concepts from West Iberia and the Alps. Int J Earth Sci 93: 432-466.

Manatschal G, Nievergelt P. 1997. A continent-ocean transition recorded in the Err and Platta nappes (eastern Switzerland). Eclogae Geol Helv 90: 3-27.

Marroni M, Pandolfi L. 2007. The architecture of an incipient oceanic basin: A tentative reconstruction of the Jurassic Liguria-Piemonte basin along the Northern Apennines-Alpine Corsica transect. International Journal of Earth Sciences 96: 1059-1078.

Masini E, Manatschal G, Tugend J, Mohn G, Flament JM. 2014. The tectono-sedimentary evolution of a hyper-extended rift basin: The example of the Arzacq-Mauléon rift system (Western Pyrenees, SW France). Int J Earth Sci 1-28. DOI: 10.1007/s00531-014-1023-8.

Mohn G, Manatschal G, Beltrando M, Masini E, Kusznir N. 2012. Necking of continental crust in magma-poor rifted margins: Evidence from the fossil Alpine Tethys margins. Tectonics 31: TC1012. DOI: 10.1029/2011TC002961.

Monchoux P. 1970. Les lherzolites pyrénéennes: contribution à l'étude de leur minéralogie, de leur genèse et de leurs transformations. Thèse, Université de Toulouse.

Moore DE, Lockner DA. 2008. Talc friction in the temperature range 25- $400{ }^{\circ} \mathrm{C}$ : Relevance for fault-zone weakening. Tectonophysics 449: $120-132$.

Mouthereau F, Filleaudeau PY, Vacherat A, Pik R, Lacombe O, Fellin MG, et al. 2014. Placing limits to shortening evolution in the Pyrenees: Role of margin architecture and implications for the Iberia/Europe convergence. Tectonics 33: 2283-2314. DOI: 10.1002/2014TC003663.

Muñoz JA. 1992. Evolution of a continental collision belt: ECORS-Pyrenees crustal balanced cross-section. In: McClay KR, ed. Thrust tectonics. London (UK): Chapman and Hall, pp. 235-246.

Olivet JL. 1996. La cinématique de la plaque ibérique. Bull Cent Rech Explor Prod Elf Aquitaine 20(1): 131-195.

Orti F, Perez-Lopez A, Salvany JM. 2017. Triassic evaporites of Iberia: Sedimentological and palaeogeographical implications for the western Neotethys evolution during the Middle TriassicEarliest Jurassic. Palaeogeography, Palaeoclimatology, Palaeoecology 471: 157-180.

Peron-Pinvidic G, Manatschal G. 2009. The final rifting evolution at deep magma-poor passive margins from Iberia-Newfoundland: A new point of view. Int J Earth Sci (Geol Rundsch) 98: 1581-1597. DOI: $10.1007 / \mathrm{s} 00531-008-0337-9$.

Peron-Pinvidic G, Osmundsen PT. 2016. Architecture of the distal and outer domains of the mid-Norwegian Vøring rifted margin: Insights from the Rån Ridge system. Mar Petrol Geol 77: 280-299.

Picazo S, Cannat M, Delacour A, Escartín J, Rouméjon S, Silantyev S. 2012. Deformation associated with the denudation of mantlederived rocks at the Mid-Atlantic Ridge $13^{\circ}-15^{\circ} \mathrm{N}$ : The role of magmatic injections and hydrothermal alteration. Geochemistry, Geophysics, Geosystems 13(4): 30. DOI: 10.1029/2012GC004121.

Pinto VHG, Manatschal G, Karpoffv AM, Viana A. 2015. Tracing mantle-reacted fluids in magma-poor rifted margins: The example 
of Alpine Tethyan rifted margins. Geochem Geophys Geosyst 16. DOI: $10.1002 / 2015 \mathrm{GC} 005830$.

Ravier J. 1959. Le métamorphisme des terrains secondaires des Pyrénées. Mem Soc geol Fr 86: 1-250.

Reynolds SJ, Lister GS. 1987. Structural aspects of fluid-rock interactions in detachment zones. Geology 15(4): 362-366.

Rouméjon S, Cannat M, Agrinier P, Godard M, Andreani M. 2015. Serpentinization and fluid pathways in tectonically exhumed peridotites from the southwest Indian Ridge $\left(62^{\circ}-65^{\circ} \mathrm{E}\right) . J$ Petrol egv014.

Rouméjon S, Früh-Green GL, Orcutt BN, IODP Expedition 357 Science Party. 2018. Alteration heterogeneities in peridotites exhumed on the southern wall of the Atlantis massif (IODP Expedition 357). J Petrol 59: 1329-1358. DOI: 10.1093/petrology/ egy065.

Roure F, Choukroune P. 1998. Contribution of the Ecors seismic data to the Pyrenean geology: Crustal architecture and geodynamic evolution of the Pyrenees. Mémoires de la Société géologique de France 173: 37-52.

Roure F, Choukroune P, Berastegui X, Munoz JA, Vilien A, Matheron P, et al. 1989. Ecors deep seismic data and balanced cross sections: Geometric constraints on the evolution of the Pyrenees. Tectonics 8: 41-50.

Rowan MG. 2014. Passive-margin salt basins: Hyperextension, evaporite deposition, and salt tectonics. Basin Research 26: 154 182. DOI: $10.1111 /$ bre. 12043 .

Saint Blanquat de M, Bajolet F, Grand'Homme A, Proietti A, Zanti M, Boutin A, et al. 2016. Cretaceous mantle exhumation in the central Pyrenees: New constraints from the peridotites in eastern Ariège (North Pyrenean zone, France). Compt Rendus Geosci 348: 268-278.

Salardon R, Carpentier C, Bellahsen N, Pironon J, France-Lanord C. 2017. Interactions between tectonics and fluid circulations in an inverted hyper-extended basin: Example of Mesozoic carbonate rocks of the western North Pyrenean Zone (Chaînons Béarnais, France). Marine and Petroleum Geology 80: 563-586.

Saura E, Oró LA, Teixell A, VergésJ. 2016. Rising and falling diapirs, shifting depocenters, and flap overturning in the Cretaceous Sopeira and Sant Gervàs subbasins (Ribagorça Basin, southern Pyrenees). Tectonics 35: 638-662. DOI: 10.1002/2015TC004001.

Sauter D, Cannat M, Rouméjon S, Andreani M, et al. 2013. Continuous exhumation of mantle-derived rocks at the Southwest Indian Ridge for 11 million years. Nature Geoscience 6: 314-320. DOI: $10.1038 /$ NGEO1771.

Schärer U, de Parseval P, Polvé M, de Saint Blanquat M. 1999. Formation of the Trimouns talc-chlorite deposit (Pyrenees) from persistent hydrothermal activity between 112 and 97 Ma. Terra Nova 11(1): 30-37. DOI: 10.1046/j.13653121.1999.00224.x.

Sibuet J-C, Srivastava SP, Spakman W. 2004. Pyrenean orogeny and plate kinematics. Journal of Geophysical Research 109. DOI: 10.1029/2003JB002514.

Skelton ADL, Valley JW. 2000. The relative timing of serpentinisation and mantle exhumation at the ocean-continent transition,
Iberia: Constraints from oxygen isotopes. Earth Planet Sci Lett 178: $327-338$.

Soto JI, Flinch JF, Tari G. 2017. Permo-Triassic salt provinces of Europe, North Africa and the Atlantic margins: A synthesis. In : Soto IJ, Flinch J, Tari G, et al., eds. Permo-Triassic salt provinces of Europe, North Africa and the Atlantic margins. Tectonics and hydrocarbon potential. Amsterdam, Netherlands: Elsevier, pp. 3-41.

Sutra E, Manatschal G, Mohn G, Unternehr P. 2013. Quantification and restoration of extensional deformation along the Western Iberia and Newfoundland rifted margins. Geochem Geophys Geosyst 14: 2575-2597. DOI: 10.1002/ggge.20135.

Teixell A. 1998. Crustal structure and orogenic material budget in the west central Pyrenees. Tectonics 17(3): 395-406.

Teixell A, Labaume P, Lagabrielle Y. 2016. The crustal evolution of the west-central Pyrenees revisited: Inferences from a new kinematic scenario. Comptes Rendus Geoscience 348: 257-267. DOI: 10.1016/j.crte.2015.10.010.

Teixell A, Labaume P, Ayarza P, Espurt N, de Saint Blanquat M, Lagabrielle Y. 2018. Crustal structure and evolution of the Pyrenean-Cantabrian belt: A review and new interpretations from recent concepts and data. Tectonophysics 724: 146-170. DOI: 10.1016/j.tecto.2018.01.009.

Thiébault J, Durand-Wackenheim C, Debeaux M, Souquet P. 1992. Métamorphisme des évaporites triasiques du versant nord des Pyrénées centrales et occidentales. Bull Soc Hist Nat (Toulouse) 128: 77-84.

Tugend J, Manatschal G, Kusznir NJ, Masini E, Mohn G, Thinon I. 2014. Formation and deformation of hyperextended rift systems: Insights from rift domain mapping in the Bay of Biscay-Pyrenees. Tectonics 33: 1239-1276. DOI: 10.1002/2014TC003529.

Vacherat A, Mouthereau F, Pik R, Bernet M, Gautheron C, Masini E, et al. 2014. Thermal imprint of rift-related processes in orogens as recorded in the Pyrenees. Earth and Planetary Science Letters 408: 296-306. DOI: 10.1016/j.epsl.2014.10.014.

Vauchez A, Clerc C, Bestani L, Lagabrielle Y, Chauvet A, Lahfid A, et al. 2013. Preorogenic exhumation of the North Pyrenean Agly massif (Eastern Pyrenees-France). Tectonics 32: 95-106. DOI: 10.1002/tect.20015.

Vielzeuf D, Kornprobst J. 1984. Crustal splitting and the emplacement of Pyrenean lherzolites and granulites. Earth and Planetary Science Letters 67: 87-96. DOI: 10.1016/0012-821X(84)90041-4.

Vissers RLM, Drury MR, Newman J, Fliervoet TF. 1997. Mylonitic deformation in upper mantle peridotites of the North Pyrenean Zone (France): Implications for strength and strain localization in the lithosphere. Tectonophysics 279: 303-325.

Wenner DB, Taylor HP. 1971. Temperatures of serpentinization of ultramafic rocks based on $\mathrm{O}^{18} / \mathrm{O}^{16}$ fractionation between coexisting serpentine and magnetite. Contrib. Mineral Petrol 32: 165-185.

Wrobel-Daveau J-C, Ringenbach J-C, Tavakoli S, Ruiz GMH, Masse P, Frizon de Lamotte D. 2010. Evidence for mantle exhumation along the Arabian margin in the Zagros (Kermanshah area, Iran). Arabian Journal of Geosciences 3(4): 499-513. DOI: 10.1007/ s12517-010-0209-z.

Cite this article as: Lagabrielle Y, Asti R, Fourcade S, Corre B, Labaume P, Uzel J, Clerc C, Lafay R, Picazo S. 2019. Mantle exhumation at magma-poor passive continental margins. Part II: Tectonic and metasomatic evolution of large-displacement detachment faults preserved in a fossil distal margin domain (Saraillé lherzolites, northwestern Pyrenees, France), BSGF - Earth Sciences Bulletin 190: 14. 